\title{
Enhanced monitoring of life in the sea is a critical component of conservation management and sustainable economic growth
}

\author{
Maurice Estes Jr. ${ }^{\mathrm{a}, *, 1}$, Clarissa Anderson ${ }^{\mathrm{b}, 2}$, Ward Appeltans ${ }^{\mathrm{c}, 3}$, Nic Bax ${ }^{\mathrm{d}, 4}$, Nina Bednaršek ${ }^{\mathrm{e}, 5}$, \\ Gabrielle Canonico $^{\mathrm{f}, 6}$, Samy Djavidnia ${ }^{\mathrm{g}, 7}$, Elva Escobar ${ }^{\mathrm{h}, 8}$, Peer Fietzek ${ }^{\mathrm{i}, 9}$, \\ Marilaure Gregoire $^{\mathrm{j}, 10}$, Elliott Hazen ${ }^{\mathrm{k}, 11}$, Maria Kavanaugh ${ }^{1,12}$, Franck Lejzerowicz ${ }^{\mathrm{m}, 13}$, \\ Fabien Lombard $^{\mathrm{n}, 14}$, Patricia Miloslavich ${ }^{\mathrm{o}, 15}$, Klas O. Möller ${ }^{\mathrm{p}, 16}$, Jacquomo Monk ${ }^{\mathrm{q}, 17}$, \\ Enrique Montes $^{\mathrm{r}, 18}$, Hassan Moustahfid ${ }^{\mathrm{s}, 19}$, Monica M.C. Muelbert ${ }^{\mathrm{t}, 20}$, \\ Frank Muller-Karger $^{u, 21}$, Lindsey E. Peavey Reeves ${ }^{\mathrm{v}, 22}$, Erin V. Satterthwaite ${ }^{\mathrm{w}, 23}$, \\ Jörn O. Schmidt ${ }^{\mathrm{x}, 24}$, Ana M.M. Sequeira ${ }^{\mathrm{y}, 25}$, Woody Turner $^{\mathrm{z}}$, Lauren V. Weatherdon ${ }^{\text {aa, } 26}$ \\ ${ }^{\text {a }}$ University of Alabama in Huntsville/NASA Ecological Forecasting Program, 320 Sparkman Drive, Huntsville, AL, USA \\ ${ }^{\mathrm{b}}$ Scripps Institution of Oceanography/Southern California Coastal Ocean Observing System, USA \\ ${ }^{\mathrm{c}}$ Intergovernmental Oceanographic Commission of UNESCO, IOC Project Office for IODE, Wandelaarkaai 7, 8400 Oostende, Belgium \\ ${ }^{\mathrm{d}}$ CSIRO Oceans and Atmosphere, Hobart, TAS 7001, Australia, Institute for Marine and Antarctic Science, University of Tasmania, 7000 Hobart, TAS, Australia \\ ${ }^{\text {e } S o u t h e r n ~ C a l i f o r n i a}$ Coastal Water Research Project, 3535 Harbor Blvd \#110, 92626 Costa Mesa, CA, USA \\ ${ }^{\mathrm{f}}$ NOAA, US Integrated Ocean Observing System, Silver Spring, MD USA \\ ${ }^{g}$ GEO Blue Planet and European Maritime Safety Agency, Lisbon, Portugal \\ ${ }^{\text {h }}$ Universidad Nacional Autonoma de Mexico, Instituto de Ciencias del Mary Limnología, Ciudad Universitaria, Mexico City, Mexico \\ ${ }^{\mathrm{i}}$ Kongsberg Maritime Germany GmbH, Sorthmannweg 21, 22529 Hamburg, Germany \\ ${ }^{\mathrm{j}}$ MAST-FOCUS,Liège University, 4000 Liège, Belgium \\ ${ }^{\mathrm{k}}$ NOAA Southwest Fisheries Science Center Environmental Research Division, 99 Pacific St. Suite 255A, 93940 Monterey, CA, USA \\ ${ }^{1}$ College of Earth, Ocean, and Atmospheric Sciences, Oregon State University, 97331 Corvallis, Oregon, USA \\ ${ }^{\mathrm{m}}$ Jacobs School of Engineering, University of California San Diego, La Jolla, CA, USA \\ ${ }^{n}$ Sorbonne Université, CNRS, Laboratoire d'Océanographie de Villefranche, Villefranche-sur-Mer, France, Institut Universitaire de France, Paris, France \\ ${ }^{\circ}$ Scientific Committee on Oceanic Research (SCOR), College of Earth, Ocean and Environment, University of Delaware, Newark, USA \\ ${ }^{\mathrm{p}}$ Institute of Coastal Research, Helmholtz-Zentrum Geesthacht, Max-Planck-Strasse 1, 21502 Geesthacht, Germany \\ ${ }^{\mathrm{q}}$ Institute for Marine and Antarctic Studies, University of Tasmania, Hobart, Tasmania, Australia \\ ${ }^{\mathrm{r}}$ University of South Florida, College of Marine Science, Saint Petersburg, Florida, USA \\ ${ }^{s}$ National Oceanic and Atmospheric Administration, US Integrated Ocean Observing System, Silver Spring, Maryland, USA \\ ${ }^{\mathrm{t}}$ Universidade Federal de São Paulo (IMar/UNIFESP), Rua Dr Carvalho de Mendonça 144, 11070-100 Santos, SP, Brazil \\ ${ }^{\mathrm{u}}$ University of South Florida, College of Marine Science, Saint Petersburg, Florida, USA \\ ${ }^{v}$ NOAA Office of National Marine Sanctuaries and National Marine Sanctuary Foundation, Silver Spring, Maryland, USA \\ ${ }^{\mathrm{w}}$ California Sea Grant, Scripps Institution of Oceanography, University of California, SanDiego, La Jolla, CA, United States and National Center for Ecological \\ Analysisand Synthesis, University of California, 735 State St \#300, Santa Barbara, California, USA \\ ${ }^{\mathrm{x}}$ International Council for the Exploration of the Sea, Science Committee, H.C. Andersens Boulevard 44-46, 1553 Copenhagen V, DK, Denmark
}

\footnotetext{
* Corresponding author.

E-mail addresses: maury.estes@nsstc.uah.edu (M. Estes), clrander@ucsd.edu (C. Anderson),w.appeltans@unesco.org (W. Appeltans),nic.bax@csiro.au (N. Bax), ninaB@sccwrp.org (N. Bednaršek), gabrielle.canonico@noaa.gov (G. Canonico), samy.djavidnia@gmail.com (S. Djavidnia), peer.fietzek@km.kongsberg.com (P. Fietzek), mgregoire@uliege.be (M. Gregoire), elliott.hazen@noaa.gov (E. Hazen), maria.kavanaugh@oregonstate.edu (M. Kavanaugh), franck.lejzerowicz@ gmail.com (F. Lejzerowicz), fabien.lombard@imev-mer.fr (F. Lombard), patricia.miloslavich@gmail.com (P. Miloslavich), klas.moeller@hzg.de (K.O. Möller), jacquomo.monk@utas.edu.au (J. Monk), emontesh@usf.edu (E. Montes), Hassan.Moustahfid@noaa.gov (H. Moustahfid), monica.muelbert@unifesp.br (M.M.C. Muelbert), carib@usf.edu (F. Muller-Karger), lindsey.peavey@noaa.gov (L.E. Peavey Reeves), esatterthwaite@ucsd.edu (E.V. Satterthwaite), joern. schmidt@ices.dk (J.O. Schmidt), ana.sequeira@uwa.edu.au, maria.kavanaugh@oregonstate.edu (A.M.M. Sequeira), woody.turner@nasa.gov (W. Turner), lauren. weatherdon@unep-wcmc.org (L.V. Weatherdon).
} 
${ }^{y}$ UWA Oceans Institute and School of Biological Sciences University of Western Australia, 6009 Crawley, WA, Australia

${ }^{\mathrm{z}}$ Earth Science Division, NASA Headquarters, Washington, DC, USA

aa UN Environment Programme World Conservation Monitoring Centre, CB3ODL Cambridge, UK

\section{A R T I C L E I N F O}

\section{Keywords:}

Biodiversity

Essential ocean variables

Marine biological data

Sustainable

Blue economy

Ecological forecasting

\begin{abstract}
A B S T R A C T
Marine biodiversity is a fundamental characteristic of our planet that depends on and influences climate, water quality, and many ocean state variables. It is also at the core of ecosystem services that can make or break economic development in any region. Our purpose is to highlight the need for marine biological observations to inform science and conservation management and to support the blue economy. We provide ten recommendations, applicable now, to measure and forecast biological Essential Ocean Variables (EOVs) as part of economic monitoring efforts. The UN Decade of Ocean Science for Sustainable Development (2021-2030) provides a timely opportunity to implement these recommendations to benefit humanity and enable the USD 3 trillion global ocean economy expected by 2030 .
\end{abstract}

\section{The importance of life in the sea}

Diversity of life is a fundamental characteristic of our planet, from its genes, cells, and organs, to organisms, populations, and communities. Feedback between life and the environment affects evolutionary and adaptive processes as well as global climate. In the sea, which represents about $95 \%$ of the biosphere, biodiversity depends on and influences water quality, other ocean state variables (temperature and nutrient, carbon, and oxygen concentration), and bottom structure (such as reefs). Our economies and well-being are linked to the diversity of life in the sea [1]. The Organisation for Economic Co-operation and Development (OECD) conservatively valued the global ocean economy in 2010 at USD 1.5 trillion, and projects that this will double to over USD 3 trillion by 2030 [2]. Tourism, recreation, aquaculture, fisheries, renewable energy, shipping, biotechnology, carbon capture and other industries depend on goods and services derived from natural capital assets [3]. These

\footnotetext{
1 Present mailing address: 81 Seabreeze Court, Inlet Beach, FL 32461; ORCID: 0000-0001-5251-2153

2 ORCID https://orcid.org/0000-0001-5970-0253

3 ORCID: https://orcid.org/0000-0002-3237-4547

4 ORCID: 0000-0002-9697-4963

5 Present mailing address: National Institute of Biology, Marine Biological Station, Fornače 41, 6330 Piran, Slovenia; ORCID https://orcid.org/ 0000-0002-9177-6626

6 ORCID 0000-0003-4251-896X

7 Orcid \#: https://orcid.org/0000-0002-4843-5746

8 ORCID \# 0000-0002-8485-7495

9 ORCID:https://orcid.org/0000-0002-3555-1115

10 ORCID:0000-0002-3726-0426

11 ORCID:0000-0002-0412-7178

12 ORCID: ORCID:0000-0001-6126-6177

13 ORCID:https://orcid.org/0000-0002-3195-032X

14 ORCID:http://orcid.org/0000-0002-8626-8782

15 Present mailing address: Universidad Simón Bolívar, Departamento de Estudios Ambientales, Caracas, Venezuela; ORCID: https://orcid.org/00000001-5409-1401

16 ORCID:0000-0003-3118-2161

17 ORCID:0000-0002-1874-0619

18 ORCID:0000-0002-3103-4479

19 ORCID:0000-0003-0795-8062

20 ORCID:0000-0002-5992-5994

21 ORCID:0000-0003-3159-5011

22 ORCID:000-0003-4900-5921

${ }^{23}$ present address, Future Earth, School of Global Environmental Sustainability, Colorado State University, 108 Johnson Dr., Fort Collins, CO 80523, USA, ORCID: 0000-0003-0177-7770

${ }^{24}$ Present mailing address: Kiel University, Center for Ocean and Society, Neufeldtstr. 10, 24118 Kiel, Germany; ORCID:0000-0002-4420-6532

25 ORCID:0000-0001-6906-799X

26 ORCID:0000-0002-3989-027X
}

industries lead in employment growth worldwide. Crucially, these industries depend on particular balances between different populations of organisms in ecological communities. Biological diversity is the foundation for the healthy production of food, novel energy resources, materials, and pharmaceuticals, as well as for tourism and cultural activities of many human societies around the world. It is in the best interest of societies everywhere to forecast abrupt or gradual changes to species and ecosystems we depend upon, and to detect and track organisms that can negatively alter ecosystem services (e.g., pathogenic, toxic, or invasive species), that pose a risk to food security or safety, and that affect the resilience of coastal biological and human communities. Monitoring changes in biodiversity is an important proxy for evaluating changes in ecosystem services [4].

A growing human population will be even more dependent on marine organisms by 2030 and beyond. Evaluating the proper uses of biodiversity for ecosystem health, economic performance, business operations, and human wellbeing is critical to sustaining this development. In recent decades, marked changes have occurred in the physical and chemical structure of the ocean. There are clear trends in sea level, temperature, surface winds, ocean circulation, oxygen concentrations, and ocean $\mathrm{pH}$ [5-7]. Many of these changes have important consequences for marine life and related biogeochemical fluxes and cycles, from the surface to the bottom of the ocean [8]. Yet, while our environmental monitoring systems have matured to help assess and forecast weather and climate, they are not sufficient to observe life in the sea. An important aspect of this challenge is to reduce gaps and enable local groups in developing nations, small island nations, and indigenous communities, promoting sustainable research and capacity development that recognize and build on traditional and indigenous knowledge. The larger challenge is to ensure that marine ecosystem services are sustained for all of society.

The UN Decade of Ocean Science for Sustainable Development (2021-2030), the "Ocean Decade" [9], provides this opportunity. On June 8, 2021, the Ocean Decade Coordination Unit of the UN endorsed the first set of Actions (Ocean Decade Actions, 2021) to advance knowledge for sustainable development and co-developing solutions through innovative, transdisciplinary co-design. The process is formulated to respect inclusivity, empower women and other minorities, including early-career professionals and indigenous knowledge holders, and encourage partnerships between the natural and social sciences, government, and all stakeholders from the public and private sector. One of the Actions endorsed is 'Marine Life 2030', a program designed to establish the globally coordinated system to deliver actionable, transdisciplinary knowledge of ocean life to promote human well-being, sustainable development, and ocean conservation. Other relevant programs are the Ocean Biomolecular Observing Network (OBON), which seeks to better understand life in the sea by analyzing its biomolecules, including DNA, and Challenger 150, which aims to advance long term monitoring in the deep sea. Marine Life 2030, OBON, Challenger 150 
and other Ocean Decade programs will unite partners into a global, interoperable network and community of practice advancing observation and forecasting of marine life. The network of networks will link technical, management and policy stakeholders to build and exchange capacity for advancing society's grand challenges of managing activities for a healthy and resilient ocean and the vibrant and healthy society that depends on it. Marine Life 2030 and OBON are closely linked with other Ocean Decade Actions, including those focused on better coordination of a Global Ocean Observing System (GOOS), ocean acidification and ocean oxygen monitoring, observing the deep ocean and air-sea interactions, and improved forecasting of ocean conditions, including ecological forecasting.

Marine Life 2030 has roots in decadal global Ocean Observation meetings $[10,11]$. During Ocean Obs'19 (September 2019, Hawaii), a ten-year implementation plan was designed to integrate biodiversity and marine life monitoring into the GOOS. These observations are the basis for monitoring the many and diverse aspects of ocean health. The plan serves the needs of society for information about the ocean within national jurisdictions, in the high seas, in coastal or pelagic regions, and from the surface to the deep ocean. Specifically, the plan proposes to:

1. Enhance collaborations between marine physical, chemical, and biological observing groups. This includes the private, academic, and government and other public sectors.

2. Increase coordination to integrate multidisciplinary measurements from physics, biogeochemistry, biology, and social sciences [12] using Essential Ocean Variables (EOVs) [13] and relevant socio-economic metrics.

3. Align the observing community to use common data and metadata standards, strengthen interoperable data and knowledge management systems, and operate within the Framework for Ocean Observing (FOO) [14, 15]. This includes following Best Practices for the collection, archival, quality assurance/quality control, and distribution of observations on EOVs [16,17] following Findability, Accessibility, Interoperability, and Reuse (FAIR) guidelines [18].

Well established technologies for biodiversity observing are available today and should be used widely with improved coordination [19-21]. Newer technologies such as remote sensing, in situ imaging, and 'omics, leveraging autonomous platforms, innovative submergence facilities and vehicles, artificial intelligence, and machine learning provide exciting new opportunities to map and monitor marine life. Building on traditional taxonomic and functional trait studies, these complementary methods extend present capabilities and provide information about local variation in a context of changes occurring at regional to global scales, and from short to longer time scales. This is required to improve the uncertainty around trends detected in biological and biogeochemical variables.

Effective, sustained ocean observing needs to address well-defined user needs and produce information that has an impact (GOOS; Fig. 1). Below, we provide key investment opportunities, driven by the societal challenges identified for the Ocean Decade.

\section{Societal challenges addressed by ocean observations}

Understanding the synergies and effects of changes that happen in organisms, from cells to communities, is a daunting task for any path towards sustainable development. In the same way that standardized and openly shared weather observations around the world are used for weather forecasts and monitoring climate change, we need interoperable and timely data on marine biodiversity to better forecast ecosystem functions and services [22,23]. The EOVs were designed for this purpose. This directly satisfies several United Nations (UN) Sustainable Development Goals [9,10,12,23,24].

Marine Life 2030 seeks to advance the implementation of the GOOS Framework for Ocean Observing, building on a collaboration between programs of the Intergovernmental Oceanographic Commission (IOC; including the GOOS Biology and Ecosystems Panel, the Ocean Biodiversity Information System/OBIS, and the Ocean Best Practices System/ OBPS) and the Marine Biodiversity Observation Network (MBON), GEO Blue Planet, the Deep-Ocean Stewardship Initiative (DOSI), the UN Environment Programme World Conservation and Monitoring Centre (UNEP-WCMC), and the Ocean Knowledge-Action Network (Ocean KAN) of Future Earth. This broad-reaching collective effort aims to improve and extend the measurement of biological EOVs globally and for all depths, recognizing that this endeavor is fundamental to developing the relevant MBON Essential Biodiversity Variables (EBVs) [24]. EOVs and EBVs synthesized through interoperable data will facilitate national and global decision makers to monitor progress against their goals and targets and enable scientists to accelerate understanding of the ocean.

The multidisciplinary collective described above seeks to tackle four societal challenges and realize sustained benefits for the Ocean Decade:

- Strengthening global food security by tracking ocean ecosystem health.

- Enhancing socio-economic resilience of coastal communities to climate change and anthropogenic stressors.

- Managing for growing exploration of the deep sea and open ocean toward sustainable development.

- Supporting seascape-level planning for sustainable development in Exclusive Economic Zones (EEZs) and Areas Beyond National Jurisdiction $(A B N J)$.

Below we list priorities for investment that are directly associated with each societal challenge. These priorities are inherently crosscutting, and several will need to be considered together to support more than one societal challenge. Together they provide a practical construct for a comprehensive observing system for ocean biodiversity.

\subsection{Societal Challenge: Strengthening global food security by monitoring ocean ecosystem health}

Fisheries and aquaculture provide a growing proportion of the world's food supply $[6,25]$. With a growing population, monitoring the health of ocean ecosystems that underpin fish production is of critical

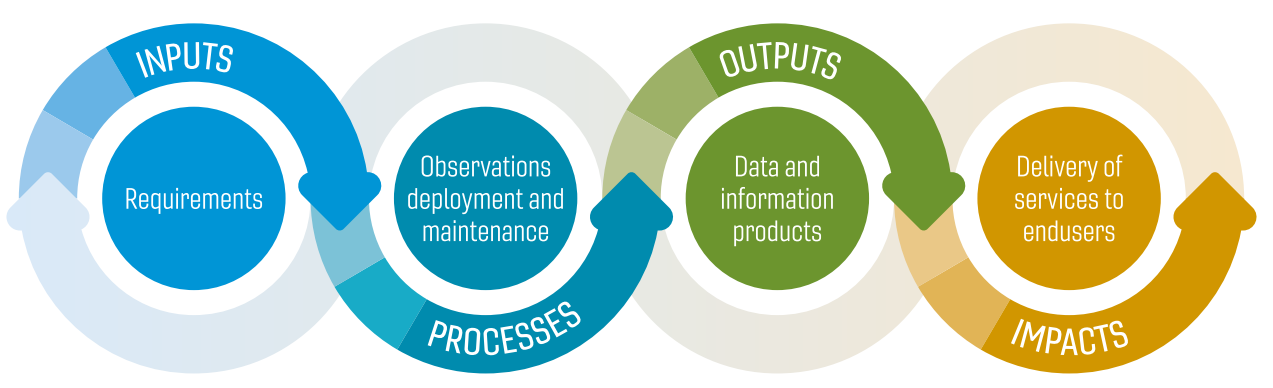

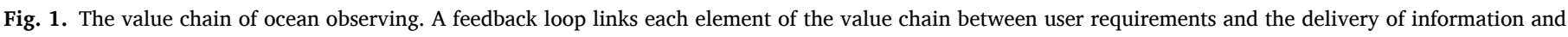
products to the users. Advancing observations and interoperability are continually reevaluated with updated user inputs. (From [14]). 
importance to global food security. This requires monitoring basic elements of the food web, including plankton, and careful accounting of the biodiversity, abundance, and distribution of organisms at higher trophic levels. Plankton are responsible for at least half of the global primary production [26]. They are susceptible to, and themselves even alter, the dynamics of ocean acidification and oxygen content [27]. Top-down trophic cascades are expected with the accelerated removal of predators and the marked susceptibility of higher trophic levels to global warming [28].

Monitoring priority \#1: Plankton- Tracking changes in 'phytoplankton and zooplankton biomass and diversity' EOVs. Characterizing and monitoring phytoplankton and zooplankton abundance and their status at local to global scales is fundamental for several economic reasons. Plankton, as the productive base of aquatic ecosystems, are a key indicator of ecosystem health. Nutrient loads in coastal areas contribute to plankton blooms that are associated with growing hypoxia and anoxia around the world [29]. This decrease in water quality leads to fish kills, shellfish bed degradation, and overall loss of economic benefits [30]. There is also a link between the timing of phytoplankton and zooplankton blooms and the abundance of fish and other commercially important species $[31,32]$. These blooms also influence the location and feeding success of migratory animals, including marine mammals and seabirds, and these trophic linkages are important indicators of overall ecosystem health [33,34]. About 25 species of zooplankton, i.e., copepods, mysids, and euphausiids are commercially harvested [6,35]. The ability to predict the presence and the timing of beneficial or harmful algal blooms is critical for many commercial interests, from local aquaculture and other aspects of the food industry, to tourism. Co-locating and joint analysis of observations of harmful algae blooms (HABs), toxins, and environmental covariates helps to improve our capacity to forecast these events [36]. Phytoplankton and zooplankton also play fundamental roles in the biogeochemical cycles of many elements including carbon, nitrogen, and other nutrients. These biological processes modulate climate, carbon storage and geological processes, modulate ocean $\mathrm{pH}$, and are an important indicator of water quality. In turn, climate changes have important impacts on the plankton diversity.

Methods to measure the plankton EOVs are well established and ready to be expanded beyond fluorometry. This includes genomic, quantitative imaging, optical spectroscopy, and active acoustics methods $[10,11,19,21,24,25]$. Best practices that converge on interoperability are within reach given advances in 'big data' science; implementation depends on collaboration $[16,17]$. Increasing the number and frequency of observations regionally and in the global ocean is an already-underway investment opportunity, with a payoff in improving our skills to forecast food production, water quality, and biogeochemistry.

Monitoring priority \#2: 'Fish abundance and distribution' EOV. Fish and fisheries are key parts of ecosystems. Fish consume lower trophic level organisms, including plankton and other fish, and are consumed by humans, marine mammals, seabirds, fish, invertebrates, and microorganisms. Fisheries are integral and often fundamental elements of economies and societies around the world and occupy important roles in traditional and modern cultures. For these and other reasons, the abundance and spatial distribution of fish of different species need to be measured routinely, widely and in a standardized manner. This helps to increase accountability. Different ecosystem-based fisheries management approaches will require different observing and forecasting strategies, and will vary in the implementation to collect information about specific EOVs and in addressing specific capacity building needs [25].

There are two main sources of information on fish: fisheries data and scientific monitoring (fisheries-independent) data. Commercial fisheries stock status is monitored with an expanding array of methods ranging from direct capture, mark and recapture and more recently genetic approaches, supported by well-developed assessment models and fisheries statistics. While there are commercially fished stocks that are yet to be monitored adequately, fisheries data can be biased as they highly depend on fishing effort and strategy. Non-target species (and habitats) that are caught alongside (even if rarely) the usually more productive target species are less frequently monitored despite their being under greater threat from fisheries that the associated target species due to their comparatively low productivity.

Many nations conduct stock assessments for valuable species within their EEZs while intergovernmental organizations conduction stock assessments for transboundary species. The Food and Agriculture Organization (FAO) of the United Nations routinely receives national fisheries data and statistics. A good example is pelagic sharks. Nongovernmental groups, such as The Sea Around Us Project [37,38], compile data from a large variety of sources to estimate fishery statistics for stocks and regions globally and attempts to correct it with bycatch estimates and other data. Other sources include many national, multinational, and regional fishery management organizations (RFMOs). Small-scale, artisanal fisheries and recreational fisheries are much less likely to be monitored and are less well documented. Because fish catch is as an integral component of the fishing business and do not cover it here.

Fish and invertebrate species that are not targeted by commercial fisheries and species that are caught alongside commercially caught species require improved monitoring. Most of these species and habitats occur in coastal waters. Impact of fisheries and other activities on coastal habitats will be improved through monitoring the 'Ocean Sound EOV' and the 'Trends in coral reef habitat extent and condition EOV' (Monitoring Priorities \#4 and \#6 below). Impacts on mobile fish and invertebrates are an important component of monitoring coastal habitats but monitoring also needs to include additional areas including offshore mid-water environments, and unconsolidated and shelf habitats.

Some information will be available from the rather restricted coverage of fishery-independent surveys, but primarily in northern temperate and polar latitudes. Underwater visual surveys, by divers in safe shallow waters and by baited underwater remote video systems (BRUVs) in other areas are proving to be useful methods for surveying mobile fish and invertebrates in coastal waters that are readily available to developing countries with only moderate resource outlays and focused training $[39,40]$. Developing a global network of underwater visual surveys for coral reefs, temperate reefs and other structured coastal habitats and a global network of BRUVs for areas inaccessible to direct observation is a priority for monitoring the impacts of fishing, habitat loss, climate change, etc. on these often most vulnerable fish and invertebrate species [41].

While fisheries independent data are costly to acquire, they are essential to monitor and evaluate the status of fish species and marine ecosystems more accurately than using only fisheries-dependent catch estimates. The GOOS Bio-Eco description of the Fish Abundance and Distribution EOV [42], provide additional guidelines on the information that may be collected for this EOV. Schmidt et al. [25] provide case studies and recommendations for the design and use of ocean and fisheries observations in management and research applications.

Monitoring priority \#3: Marine Megafauna: Tracking changes in 'marine turtles, birds, and mammal abundance and distribution' EOVs. Both within and between national jurisdictions, marine megafauna are instrumental in shaping the structure and function of marine ecosystems. The migratory routes are part of muti-species networks that lead to biodiversity hotspots in different places in the ocean at different times. They exert top-down population density and trophic control, link ecosystems over large scales through their migrations, and play important roles in nutrient distribution through excretion and egestion away from feeding grounds. Marine megafauna are also of high social, cultural, historic, conservation, and economic value $[43,44]$.

Animal tracking is a mature form of ocean observing that informs conservation policy around the world $[45,46]$. Animals outfitted with sensors play a major role in collecting data about the environment, animal population location and range and essential habitat, animal communication strategies, and the effects of sound exposure on animals 
[46]. These efforts are often collectively called 'biologging'. Many of these animals travel to difficult-to-reach areas (e.g., under ice sheets) and increase spatial and temporal coverage of monitoring across biological, physical and climatic EOVs [13,14]. Investments in animal tracking technologies and coordinated efforts are required to advance standardization, interoperability, and integration into assessments and forecasts [47]. The expansion of national and regional animal telemetry networks and improvements in biologging devices are promising developments in this regard.

Monitoring priority \#4: 'Ocean Sound' EOV: Acoustic baselines, metrics of biodiversity and ecosystem health. Sound measurements are used to characterize biology, ecosystem interactions, and anthropogenic impacts across seascapes [48-51]. The significance of increasing anthropogenic sound on ocean biodiversity is well established [52]. Passive acoustic monitoring (PAM) is used for non-invasive time series measurements of fish, marine mammals, invertebrates, and can be used to characterize habitats and monitor life from local to basin-scales $[49,53]$. Active acoustics are used in fish stock assessment, for plankton and ichthyoplankton mapping, and benthic habitat exploration, characterization, and mapping at shallow to full-ocean depths [54]. Acoustics provide a quantitative and often cost-effective way to measure noise and assess biodiversity, compare soundscapes across habitats, and evaluate management actions (e.g., in marine protected areas) [49,53,55-57]. When acoustic data is integrated with other information such as increasing vessel traffic patterns, animal stress hormones, animal physiology, and environmental variables, it is possible to estimate effects of urbanization, human population growth, mining and defense activities, an increase in maritime activity, associated economic expansion [52], and climate variability [50]. Well-coordinated, long-term ocean sound observation systems can produce multi-dimensional time-series datasets with which to characterize soundscapes and the interconnections of overlapping biological, physical, and manmade sound sources [58]. Economic monitoring of the ocean requires a baseline and subsequent acoustic surveys of water column biomass (fish, plankton), benthic biota and habitats, and human-generated sounds at the regional to global scales that complement the Seabed 2030 project, an international initiative to map the bathymetry of the ocean by 2030 [59-61].

\subsection{Societal challenge: enhancing socio-economic resilience of coastal communities to climate change and anthropogenic stressors}

Monitoring priority \#5: Marine Macrophyte Habitats: Trends in 'macroalgal, seagrass, and mangrove cover, composition and condition' EOVs. Marine macrophytes (aquatic plants large enough to be seen with the naked eye) include a wide variety of seagrasses, mangroves, and macroalgae (kelp, Sargassum, green, and red algae). They are the foundation for many shallow ecosystems and form important floating habitats used by many species of commercial, subsistence, and conservation interest $[62,63]$. They provide critical habitats that support important fisheries worldwide. Macrophytes are also essential for coastal stability and protection from extreme weather events and sea level rise. In the USA alone, storm protection from coastal wetlands has been valued at more than USD 23 billion per year [64]. Mangroves protect coastal areas from erosion and damage from storm surges, filter terrestrial run-off, supply timber, provide critical nursery habitat for marine species around the world, and generate significant revenue through ecotourism and biodiversity conservation. Seagrasses are also often highly productive, and also provide essential habitat and nursery areas for different commercially and ecologically important species of finfish, shellfish, and megafauna including sea turtles, dugongs, and manatees. Macrophytes help stabilize and protect coasts. They support high water quality by trapping sediment and absorbing nutrient runoff. Kelp forests are estimated to contribute about USD 1 million per kilometer of coastline without accounting for indirect and non-use values [65]. The harvest of some macrophytes for human food, materials, and pharmaceuticals is a growing industry $[6,66]$.

All macrophytes and their habitat are recognized for their carbon storage, and they are now being taken into account in international carbon credit markets $[63,67]$. They serve as buffers for pollution and can mitigate ocean acidification. Conserving and restoring seagrass meadows is a key action for countries to advance 26 targets and indicators associated with at least ten of the UN Sustainable Development Goals [13]. However, some macroalgae cause havoc and can smother other habitats, such as shallow tropical coral reefs. Some have caused detrimental economic impacts when their growth and distribution patterns change, such as has occurred with Sargassum in the tropical Atlantic $[68,69]$.

Monitoring the diversity, geographic extent, and health of marine macrophyte habitats is an enormous scientific and practical challenge. It requires a coordinated community of practice and new approaches. Investments such as these encourage ecological monitoring in support of economically resilient coastal communities and the global restoration agenda including the UN Decade of Ecosystem Restoration [https:// www.decadeonrestoration.org/].

Monitoring priority \#6: Coral Reef Habitats: Trends in 'coral reef habitat extent and condition' EOVs. Shallow-water tropical coral reef habitats are an important element for economic monitoring. They provide food, recreation, cultural values, and other direct benefits to over half a billion people in over 100 countries, contributing on the order of a trillion USD each year to the global economy [70]. Coral reefs are among the most biologically diverse ecosystems. New imaging and remote sensing technologies are now being used to complement historical survey methods [71]. The threats that local and global stressors, including climate change, acidification, pollution, overfishing, tourism, invasive species, and disease pose to these delicate ecosystems means that investments in aggregating observations of ecosystem biodiversity are crucial, now. The Coral Reef Sentinels program endorsed by the Ocean Decade, for example, is an important initiative to deploy autonomous, low-cost robots to monitor the health of coral reefs around the world in near real-time.

\subsection{Societal challenge: managing the growing exploration and use of deep sea and open ocean toward sustainable development}

Monitoring priority \#7: Benthic and deep-ocean biodiversity. The deep ocean represents $85 \%$ of the ocean. Marine sediments cover a very large surface area of the Earth and represent an important habitat where cycling and sequestration of organic carbon represents a very important regulating service. Deep water and benthic organisms play important roles in the marine ecosystem. Benthic biota disturb and rework sediments, they are important sources of sink of carbon and nutrients, or as food for others. Many have lives that span decades to hundreds of years. Coastal benthic communities are frequently used as operational indicators of water quality. More broadly, the continental shelves of the world support very large fisheries of benthic invertebrates and fish. Yet, continental shelves and benthic marine regions below $200 \mathrm{~m}$ depth are among the least observed regions of the planet [54]. They serve as habitat for species we need to understand better, and almost certainly other species not yet identified. Further study of the deep-sea environment is especially important given the linkages between the marine surface, the atmosphere, and water column across depths [54]. Deep-ocean biodiversity comprises important ecological and economic resources, including microorganisms, corals, and sponges that are used for pharmaceuticals and bio-materials [72,73]. Some organisms are involved in the biogeochemical precipitation of vast amounts of rare-earth elements targeted by active mining, conservation, and policy interests $[74,75]$.

There are questions about the sustainable exploitation of deep ocean organisms and materials due to the combined stresses of climate change, pollution, habitat disturbance, and extraction of slow-growing organisms. This drives the urgency to explore, characterize, and map the 
diversity of deep ocean life and habitats, and for adaptive management and conservation strategies in areas of national jurisdiction and areas beyond national jurisdictions. The Deep Ocean Observing System (DOOS) has proposed interdisciplinary projects across potential region specific sites to further sustainable deep ocean observing efforts $[54,76]$. In June 2021, the Ocean Decade endorsed several programs focused on different aspects of deep ocean biodiversity observation (the Deep Ocean Observing Strategy, Joint Exploration of the Twilight Zone Ocean Network, One Ocean Network for Deep Observation, Challenger 150, the International Ocean Discovery Program, and Marine Life 2030; see [77]).

\subsection{Societal challenge: supporting seascape-level planning for sustainable development in EEZs and ABNJ}

Priority methods \#1: Seascapes. Capturing changes in regional biogeography. Seascapes are dynamic, biogeographic maps derived through a thematic classification of multiple observations of the ocean [78]. They help to understand whether groups of organisms could be present in an area given particular sets of environmental conditions [79]. Surface ocean seascape maps are now available routinely (NOAA CoastWatch). Such remote sensing products extend the inferences made from localized field observations to larger regions and to the entire global ocean.

An important additional need is to enable habitat characterization in three and four dimensions to improve ecological forecasting and applications [80]. This requires expanding ocean biological-ecological EOVs (plankton abundance; marine megafauna distribution, seagrass, mangrove, macroalgae, coral cover, and soundscapes) [81] in large, standardized databases such as the World Ocean Atlas.

There are several important areas of investment to improve seascape monitoring for societal benefit. New hyperspectral satellites promise information on phytoplankton functional types, water quality, and shallow benthic habitats. The Landsat 7 and 8, and Sentinel 2 sensors have been used in many coastal studies, complementing the coarser resolution global ocean observing satellites. An opportunity lies in developing consistent global operational products to address coastal and aquatic issues, including wetlands and shallow benthic habitat mapping. The NASA Plankton, Aerosol, Cloud, ocean Ecosystem (PACE) satellite, the Geosynchronous Littoral Imaging and Monitoring Radiometer (GLIMR) instrument, and the NASA Surface Biology and Geology (SBG) mission will advance global and regional biodiversity and ocean health measurements $[82,83]$. Routine coastal ocean products would revolutionize our ability to characterize potential aquaculture sites, monitor pollution, and observe plankton distribution in estuaries and other coastal areas. Satellite observations also are useful for evaluation of shoreline disturbance from severe storms, oil spills and other stressors over large areas. Space-based lidars have already shown exciting potential to detect plankton, including zooplankton, distribution and dynamics [84]. Such information helps characterize the subsurface vertical distribution of plankton and help map plankton during the night and in high latitude areas where solar irradiance is low for part of the year. This is a key to improving productivity models. Atmospheric polarimeters improve remote sensing of the composition of ocean particles [85]. Suborbital observations, such as those from aircraft and drones, are important for monitoring biological changes at the ocean surface, in coastal zones, and in shallow optically-clear bottom habitats at what can be very high spatial resolutions (e.g., $10 \mathrm{~s}$ of centimeters scale).

Validated seascape maps with associated accuracy assessments should be integrated into economic monitoring efforts to advance forecasting of ecosystem functions. They should be made available in a format that helps to manage a growing number of sectors interested in operating within national waters, informing renewable and nonrenewable energy strategies, coastal infrastructure development, and other activities. Investments are required to support the development of applications that integrate field and remote sensing data, and help forecasts of biodiversity and seascapes. The Digital Twins of the Ocean (DITTO), a recently endorsed UN Ocean Decade action proposal, will play an important role in infrastructure development and other activities both in the coastal and ocean scenarios.

Priority methods \#2: 'Omics - Realizing the enormous potential of biomolecular ecology. Environmental DNA (eDNA) methods detect the presence of individual species and are now used to survey which organisms, from microbes to marine megafauna, may have been present in an area over several days $[86,87]$. Harnessing molecular methods requires an open-access paradigm following Genomics Standards Consortium (GSC) standards [88]. For example, the Minimum Information about any (X) Sequence (MIxS) and other schemas like Darwin Core for taxonomy are now being linked for interoperability.

In addition to eDNA, genomics methods are now being used monitor ecosystem function and to census high profile species [86,89]. Further applications continue to develop. Omics approaches, including eDNA, are important areas of investment, specifically to improve and to standardize sample collection and processing methods, to expand genetic libraries to identify taxonomies, to have ongoing accuracy assessments, to standardize and broadly adopt data and metadata management schema, and to incorporate these observations into the GOOS framework in order to advance ecological forecasting.

Priority methods \#3: Applied Models. Advancing ecological forecasting. Society benefits from a capacity to forecast variables that affect the economy and its future well-being. Ecological forecasting of biodiversity has significant potential to advance management and identify trade-offs among human activities [90]. Skillful forecasts of weather and physical ocean conditions today are possible for daily and longer time scales. These models assimilate broad and near-real-time high-quality observations of physical EOVs (temperature, salinity, sea level, and meteorological observations) [91,92]. This operational capability has lagged for biodiversity and biological observations generally [93-95].

Today, various statistical models are used to assess and predict biodiversity patterns based on forecasts of habitat change [96]. Many useful indicators are now derived as now-casts at high spatial and temporal resolution (hours, kilometers) [97,98]. Investments in ecological forecasting are needed to make models more mechanistic and move models generally to operational applications to help make decisions, e.g., about the overlap between areas of ecological significance and human activities [99]. Advances now allow forecasting the timing and location of HABs, the occurrence of hypoxia, patterns of ocean acidification, the timing of pathogens, and inform fisheries management, including efforts to decrease bycatch or interaction with megafauna by using species distribution models [100,101].

Priority methods \#4: Data management. Cleaning up and organizing our data inventories. An investment in knowledge management is needed to organize information and data. Over the past decade, more data have been collected each year from autonomous platforms about the physical and chemical state of the ocean than in the entire century before [90]. Oceanographic data streams are generally not interoperable, are collected by different methods or devices, are stored in different formats, and are often housed in disconnected databases or the personal computers of individual observers. Many data centers restrict access to information, yet at least 24 international treaties and conventions need information on the status of the marine environment, anticipating an expansion of geographic ocean coverage [13]. An important element is to bring historical measurements into this common framework, to assess how biodiversity, including the abundance of organisms and different habitats, has changed from previous states.

Among the greatest challenges we face is solving the puzzle of identifying a minimum set of specific EOVs that globally distributed research groups will adopt through sometimes tedious discussions, review, and coordination for wider use by humanity. An analogue are the Essential Climate Variables (ECVs) identified by the Global Climate Observing System (GCOS), which is, in turn, co-sponsored by the World Meteorological Organization (WMO), the IOC, UNEP, and the 
International Council for Science (ICSU). While biodiversity arguably has more dimensions of complexity than global climate, programs still need to converge on a few common measurements conducted using agreed-upon methods (best practices), while retaining the flexibility to conduct a wider suite of physical, chemical, biological, and geological observations. Following standard field and data management protocols around the world will make it possible to test reproducibility, refine uncertainty estimates, and compare observations over space and time so that biological changes observed at a location can be explained in a regional or global context.

Best practices are fundamental to consistent monitoring from place to place, change detection over time, accurate interpretations of change, improved ecological forecasting, and the documentation of data provenance while also recognizing data providers $[16,17]$. FAIR data standards are a key for the success of this strategy [18,102]. Standardized protocols ensure interoperability across sites and networks. Metadata detailing specifics of samplers and how they were used help distinguish sampling variability from trends. Where feasible, such as when a new monitoring effort is established, MBON, OBIS, and GOOS BioEco recommend the adoption and implementation of the data standards and sharing data via the Environmental Research Division's Data Access Program (ERDDAP) $[18,103,104]$. While data standards for taxonomy (Darwin Core) and 'omics (MIxS) have evolved and are converging toward some integration, many other data types, including passive and active acoustics, imaging, and animal tracking still require convergence on standards or have just made first steps towards full data standardization [47].

\section{Next steps}

Sustainable development requires timely and relevant information about human activities that depend on and affect life in ocean and coastal areas. Fig. 2 shows specific goals and milestones to enable the collection and use of this information and its transformation into actionable knowledge. Fundamental steps include strengthening partnerships and adopting the concept, language, and framework of the biological EOVs, beginning with the priorities listed above. Many of these EOVs are already Essential Climate Variables (ECVs) [105], highlighting their importance in understanding climate and climate impacts on life. Failure to focus on these monitoring priorities will be far more costly than the implementation of an integrated ocean observing plan [106], with costs measured in resources and in human lives.

The Ocean Decade offers an opportunity to lower costs of access to information, of sensor deployment and recovery, increasing reliability of sensors, observing platforms, and forecasts, and to advance human capacity. Scientific observations need to be collected based on needs identified from socio-economic indicators. The NASA Socioeconomic Data and Applications Center (SEDAC) and the International Renewable Energy Agency (IRENA) procure societal information to help design and evolve biodiversity indicator applications. Some sectoral data are not openly available due to their sensitive commercial nature (e.g., fisheries, petroleum and gas extraction, etc.). Collaborations based on respect and trust may help produce useful indicators by aggregating these data and hiding sensitive details. For example, the Food and Agriculture Organization reports historical catch levels of fish and invertebrates for many areas and can be supplemented with socio-economic data [6]. Targeting specific applications requires partnerships between ocean observers and local, regional, indigenous, and national governments in order to strengthen inclusion of different knowledge systems, and to improve the alignment of monitoring efforts with societal needs.

Information collected over time is essential to measuring and evaluating the outcome of policies and human behavioral changes and changes related to ecological and environmental conditions. Such outcomes and social changes in principle generates feedback that can improve the entire ocean observing value chain (Fig. 1). However, most marine biological and ecological observations are collected today through research projects of limited duration. A successful approach needs to recognize that biodiversity monitoring requires ongoing investment to address societal priority areas in a sustained way. Observations collected periodically, at the proper frequency over time. are needed to understand uncertainty and variability, and to detect phenomena of interest. Time series are required to develop baselines and climatologies against which to compute anomalies, to evaluate changes in phenology and in age structure of populations, to assess the interdependence of organisms, and to quantify trends or detect abrupt or small changes in populations or in geographic distribution that can lead to significant ecological change over long periods. Time series provide the information needed to characterize variability, reduce uncertainty, and to increase the skill of forecasts. In addition to prioritizing the sustained collection of data for biological EOVs and EBVs to address specific issues, maintaining existing historical time series data at International Long Term Ecological Research Sites (ILTERS) and other established sites helps to establish the historical data needed to determine global trends and local pressures that can be evaluated against natural variation for policy and decision-making [107].

Capacity sharing and development are crucial to establish and maintain operational monitoring efforts and enhancing interoperability around the world. There are many capacity development efforts already underway in ocean science and applications [108]. These programs can better document, share, and incorporate traditional and local knowledge as a foundation for inclusion and representativeness in the definition of policy options. Infrastructure and resources are not spread evenly across the globe $[109,110]$. For example, $69 \%$ of students participating in international conferences held between 2011 and 2018 came from Europe and Northern America. Nearly 70\% of global marine science publications between 2012 and 2017 came from the same regions. So, infrastructure is not evenly spread, not equally well supported throughout the world, and not well connected to operational, commercial, or academic stakeholders who need information about the ocean.

Coordinating this capacity will increase the chances of sustainable use of natural resources and will also sustain resource monitoring and management. Successful capacity development hinges on effective longterm engagement with local communities and key stakeholders from local to international scales where societal and scientific requirements determine the data that are collected and utilized by various end users and sectors of society [111]. Effectively, capacity development needs to be coupled with societal needs and the availability of employment for those trained. Also, observation networks should strive to work within the GOOS framework and communicate and integrate across all levels: local, regional, national, and international, recognizing and valuing local and traditional knowledge.

Any and all investment in existing or new monitoring efforts and infrastructure supports a more comprehensive observing system. However, additional investment in long term monitoring efforts is essential in countries that lack resources or expertize, particularly in the southern hemisphere, in coastal Africa, South America, Southeast Asia and Small Island Developing States. Some of these regions have very high biodiversity that should be a high monitoring priority because they are also sites of high development pressure and high social vulnerability. The dichotomy that developed during the COVID-19 pandemic in 2020-2021, in which many of these countries remain in economic stagnation as a result of differing economic recovery programs and imbalance in the access to vaccine, has further decimated basic and applied science programs. The result is that traditionally disadvantaged communities are at even higher risk of losing basic ecosystem services.

Opportunities exist to enhance capacity development by using data portals and information/knowledge hubs combined with training, to enable coastal states to utilize and provide data without needing their own information technology infrastructure or data management capability. Capital should be mobilized for technologies to benefit underserved markets, including innovative financial instruments with both government and private industry participation, investment in low- 
Advocacy and visibility across stakeholders

- OceanObs19 recommendations communicated to stakeholders

Contributed to UN Decade planning

Contributing networks identified
Governance structures designed and coordinated
Implementation plans developed and socialized

Network funding and resources identified

- Promoted best practices and FAIR data use

Data architecture

- Capacity development, technology transfer and citizen science plans

Metrics to measure success and impact

- Multivariable measurements enabled across platforms

Integration of novel technologies and sensors

- Automated measurements facilitated by technological innovation

'Start-up' kits for capacity development and citizen science

Calibration and quality control standards established

Observations maintained and strengthened

- Observations expanded to fill geographic gaps

Pilot projects planned and initiated

Sentinel sites planned

Data delivery and modeling products operationalized

National and global policy assessments

Participation extended to stakeholders and end-users

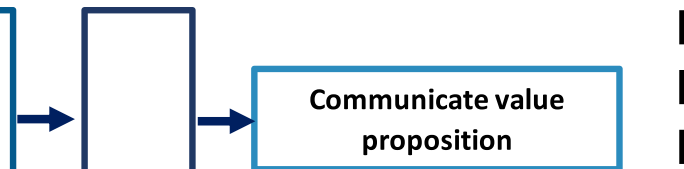

Strengthen partnerships and develop leadership

Build the foundation for implementation

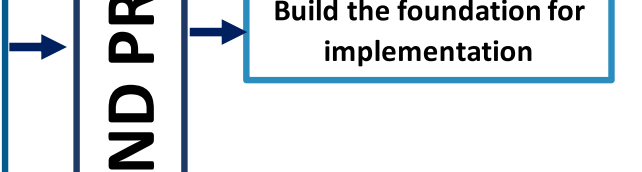


rescue.

\section{Criteria for success: ocean monitoring in national accounting}

If ocean observations are to be sustained, they must meet the societal needs identified above and provide clear outcomes with associated milestones that will deliver impact to identified users (including science itself) (Fig. 2). In Table 1, we summarize how the identified monitoring priorities link societal needs to impacts and outcomes. The Blue Paper on National Accounting for the Ocean and Ocean Economy published by the High Level Panel for a Sustainable Ocean Economy [114] recommends that national statistics offices work with ocean observing groups to identify marine data that can be used in national accounts. This process is already underway with substantial efforts to promote convergence of ocean accounting initiatives. This is occurring in the context of sustainable development (e.g., the Global Oceans Accounts Partnership ${ }^{27}$ ) and with the UN Convention on Biological Diversity, as the post-2020 Global Biodiversity Framework (GBF) is consistent with UN System of Environmental-Economic Accounting (UN SEEA) Ecosystem Accounts [115]. The monitoring priorities presented here are well-suited for consideration in the UN SEEA.

The priorities listed here represent a package that is far more valuable than its individual pieces. The synergy between components will result in a comprehensive view of the state of ocean biology, its diversity, and the role it plays for humanity. We are currently not fully benefiting from information we are collecting with existing technologies, and it is important that we improve this to provide a sound platform on which to add new and upcoming technologies. This information will be useful for prediction and it will benefit humanity in the current and future generations.

\section{Conclusions}

We are at a critical juncture for observing and monitoring the status of ocean biodiversity. While it is clear that many of our more vulnerable and high-profile species are in decline (e.g., oceanic sharks [116]), others are returning after the cessation of over-harvesting (e.g., humpback whales, [117]) illustrating what policy makers and researchers can achieve when we have the information and shared concern. To act, decision-makers require clear, unambiguous information and a structure in which to make decisions, but much of our existing ocean biodiversity observing efforts have only recently started to organize and coordinate globally [9]. This is at least partly because these observing efforts are mostly funded through research funding, where innovation and new ideas are important determinants of success and funding renewal. The new and exciting technologies that are now becoming available come with the risk that the ocean biodiversity observing community will once again become more, rather than less, fractured.

Substantial progress has been made for researchers and decision makers from around the world to convene and collectively highlight areas of biodiversity observations ripe for innovation, advancement, and cohesion. Here, we have outlined biodiversity monitoring priorities that directly link to pressing societal challenges. It is critical that the global observing community converge on these shared goals and deliverables in a swift and coordinated fashion.

For example, there are currently more than 500 multilateral environmental agreements (MEAs) which address transboundary global environmental issues including biodiversity loss, climate change, and pollution [118]. MEAs raise awareness, gather information, and promote coordinated action of signatories to the individual MEA, but are not good at sharing goals and information among them. Similar to what occurs in scientific domains, we expect that they need to highlight their differences to justify continued investment. Assessing the needs of 23

Table 1

Linking challenges with outcomes for the Ocean Decade.

\begin{tabular}{|c|c|}
\hline Societal challenges & Monitoring priorities \\
\hline $\begin{array}{l}\text { Strengthening global food } \\
\text { security by monitoring } \\
\text { ocean ecosystem health }\end{array}$ & $\begin{array}{l}\text { Changes in plankton } \\
\text { biomass and diversity, } \\
\text { fish and invertebrate } \\
\text { abundance and } \\
\text { distribution, } \\
\text { Marine megafauna } \\
\text { abundance and } \\
\text { distribution, Optics } \\
\text { Imaging/microscopy } \\
\text { (taxonomy) } \\
\text { Active acoustics } \\
\text { Passive acoustics } \\
\text { 'Omics/eDNA }\end{array}$ \\
\hline
\end{tabular}

Status and trends of soundscapes and noise pollution in the ocean 1. Passive acoustics

Enhancing socioeconomic resilience of coastal communities to climate change and Seascape-level planning to guide sustainable development in national waters and in the high seas

Managing for exploration and sustainable development in the deep sea and open ocean
Trends in macroalgal and seagrass cover, composition and condition;

Fish and invertebrate abundance and distribution Marine megafauna abundance and distribution

Trends in coral reef habitat extent and condition Soundscape monitoring

Capturing changes in regional biogeography through seascapes

Advancing ecological forecasting

Cleaning up and organizing our data inventories

Capacity development and coordination Trends in deep-ocean biodiversity
1. A healthy and resilient ocean 2. A productive ocean 3. A predicted ocean Food web and ocean health assessments

Food quality and quantity Fisheries stock assessments, projections Habitat suitability and water quality nowcasts and forecasts

Biogeochemical cycle assessments Carbon and climate predictions Improved understanding of biodiversity, biomass, species occurrence, distribution and behavior, species interactions, human uses, acoustic stressors; advanced ecosystem-based management, impact and climate vulnerability assessments Long-term benefits in human well being:

1. A safe ocean

2. A predicted ocean

3. Sustainable fisheries management Ecosystem health, extent of nurseries for organisms Coastal protection assessments

Improved management and policy

Enhanced industries (pharma, materials, fisheries, tourism) Education An accessible ocean Understanding ecosystem extent for use and conservation planning A predicted ocean

A transparent Ocean Transparency in information origin, quality, access, interoperability, and application Advances in innovation, energy development, and economic growth: An inspiring and engaging ocean A predicted ocean Management, sustainable mining and fishing, conservation Understanding deep ocean connectivity An inspiring and engaging ocean

(continued on next page) 
Table 1 (continued)

\begin{tabular}{lll}
\hline Societal challenges & Monitoring priorities & $\begin{array}{l}\text { Enabled outcomes } \\
\text { exhaustive) }\end{array}$ \\
\hline & Marine megafauna & A healthy and resilient \\
ocean & Managing food web \\
distribution & structure and interactions \\
& Minimizing bycatch \\
& Enhanced tourism \\
\hline
\end{tabular}

a Bold text refers to Ocean Decade societal outcomes [8].

global MEAs that require information relevant to the EOVs [13], Rogers et al. [119] found that 14 required information on species and habitats, 11 on the sustainable management of living resources, 10 on environmental pollution, etc. There is a redundancy in information requirements and a plethora of ways in which information is required, providing scientists the opportunity to justify the continued variety and development of research objectives and technologies on the basis that at least one group of decision makers has stated that they need this information. Failing that, science itself thrives on new questions and conjectures.

We need more communication among researchers, policy and decision makers, and the industry sector. Policy makers often clearly identify what information they need. Ocean scientists, technologists, and local, traditional, indigenous groups all provide different pieces of useful information. Increasingly, society and the public at large generates information that is valuable and other information that in turn helps to focus an observing system. Promoting inclusiveness of these groups and perspectives is key for the sustainability of data gathering at the local level, i.e., the concept of co-design and co-ownership. This means working with groups other than those that the natural and social scientists, the public sector, and government have worked with. It also means investing in and extending observing strategies to new geographies, and directly engaging highly vulnerable communities everywhere, including indigenous groups and tribal nations, Least Developed Countries, and Small Island Developing States.

The Ocean Decade provides an ideal opportunity to promote this engagement. The seven decadal outcomes have been designed with the purpose of supporting sustainable development through the major ocean-relevant policy documents [120]. In this paper, we have identified some of the ocean biodiversity observation priorities that will be needed to meet these outcomes and have highlighted the goals of the recently endorsed UN Decade program, including Marine Life 2030, the Ocean Biomolecular Observing Network (OBON), GOOS, and Ocean Practices for the Decade. At the same time, MEAs are now converging on goals and targets, with links to the SDGs, and addressing the priorities that nations define through the CBD and FAO. The UN SEEA and MEAs are vehicles to identify common biodiversity variables that National Statistical Offices then collect for governments to report on ecosystem status and trends.

The private sector is an important group that needs to be part of the conversation and the implementation of these priorities. Activities and actions will now be planned as part of the Ocean Decade programs. These activities should include all stakeholders of ocean observing, including the private sector and industry.

The policy, research, private, and applied operational communities need to build on these trends, identify key information requirements, and co-develop activities that lead to progress towards a sustainable ocean for future generations. This approach will provide the purpose and direction to galvanize the ocean observing community to build the integrated system that is so critical for sustainable economic growth.

\section{Acknowledgments}

We are grateful for the support of the NASA Applied Sciences Office, Biodiversity \& Ecological Forecasting Program to Maurice G. Estes, Jr,
Grant NNM11AA01A, for funding support for the Ecosystem Health and Biodiversity session at OceanObs19, manuscript preparation and publication charges. Frank Muller-Karger and Enrique Montes received partial support from NOAA Grant NA19NOS0120199, NASA Grants NNX14AP62A and 80NSSC20K0017, NSF Grants 1762493 and 1728913 and the Gulf of Mexico Coastal Ocean Observing System. Ana M.M. Sequeira was supported by a 2020 Pew Fellowship in Marine Conservation and an ARC DP210103091. Jacquomo Monk and Nina Bednaršek were supported by the Australian Government's National Environmental Science Program Marine Biodiversity Hub. The authors also appreciate the support from colleagues that contributed to the manuscript content and provided editorial suggestions including; Margaret Leinen/Scripps Institute of Oceanography, Minhan Dai/Xiamen University, Nick Rome/Consortium for Ocean Leadership, Mitch Roffer/ retired - Roffers Ocean Forecasting and Fishing Service, Brendal Townsend/Dalhousie University, Gary Geller/NASA Applied Sciences, Sophie Clayton/Old Dominion University, Raphael Kudela/University of California, Santa Cruz, David Obura/Coastal Oceans Research and Development - Indian Ocean, Emmett Duffy/Smithsonian's Tennenbaum Marine Observatories Network, Emmanuel Boss/University of Maine and Carlo Fezzi/University of Trento. This is the first publication of the UN Decade Program - Marine Life 2030 (ML2030/1).

\section{References}

[1] J.S. Golden, J. Virdin, D. Nowacek, P. Halpin, L. Bennear, P.G. Patil, Making sure the blue economy is green, Nat. Ecol. Evol. 1 (2017) 17, https://doi.org/ 10.1038/s41559-016-0017.

[2] OECD, Rethinking Innovation for a Sustainable Ocean Economy, OECD Publishing, Paris, 2019, https://doi.org/10.1787/9789264311053-en.

[3] K. Leach, A. Grigg, B. O'Connor, C. Brown, J. Vause, J. Gheyssens, L. Weatherdon, M. Halle, N.D. Burgess, R. Fletcher, S. Bekker, S. King, M. Jones, A common framework of natural capital assets for use in public and private sector decision making, Ecosyst. Serv. 36 (2019), 100899, https://doi.org/10.1016/j. ecoser.2019.100899.

[4] S.R. Palumbi, P.A. Sandifer, J.D. Allan, M.W. Beck, D.G. Fautin, M.J. Fogarty, B. S. Halpern, L.S. Incze, J.A. Leong, E. Norse, J.J. Stachowicz, D.H. Wall, Managing for ocean biodiversity to sustain marine ecosystem services, Front. Ecol. Environ. 7 (2009) 204-211, https://doi.org/10.1890/070135.

[5] Intergovernmental Science-Policy Platform on Biodiversity and Ecosystem Services, IPBES. Summary for policymakers of the global assessment report on biodiversity and ecosystem services (Version summary for policy makers). Zenodo, 2019. http://doi.org/10.5281/zenodo.3553579.

[6] FAO, The state of world fisheries and aquaculture 2020. Sustainability in Action, FAO, Rome, 2020, https://doi.org/10.4060/ca9229en.

[7] IPCC, IPCC Special Report on the Ocean and Cryosphere in a Changing Climate [H.-O. Pörtner, D.C. Roberts, V. Masson-Delmotte, P. Zhai, M. Tignor, E. Poloczanska, K. Mintenbeck, A. Alegría, M. Nicolai, A. Okem, J. Petzold, B. Rama, N.M. Weyer (eds.)], 2019.

[8] L.A. Levin, D.J. Amon, H. Lily, Challenges to the sustainability of deep-seabed mining, Nat. Sustain. 3 (2020) 784-794.

[9] V. Ryabinin, The UN decade of ocean science for sustainable development, Front. Mar. Sci. 6 (2019), https://doi.org/10.3389/fmars.2019.00470.

[10] N.J. Bax, P. Miloslavich, F.E. Muller-Karger, V. Allain, W. Appeltans, S.D. Batten, L. Benedetti-Cecchi, P.L. Buttigieg, S. Chiba, D.P. Costa, J.E. Duffy, D.C. Dunn, C. R. Johnson, R.M. Kudela, D. Obura, L.M. Rebelo, Y.J. Shin, S.E. Simmons, P. L. Tyack, A response to scientific and societal needs for marine biological observations, Front. Mar. Sci. 6 (395) (2019), https://doi.org/10.3389/ fmars.2019.00395.

[11] G. Canonico, P.L. Buttigieg, E. Montes, F.E. Muller-Karger, C. Stepien, D. Wright, A. Benson, B. Helmuth, M. Costello, I. Sousa-Pinto, H. Saeedi, J. Newton, W. Appeltans, N. Bednaršek, L. Bodrossy, B.D. Best, A. Brandt, K.D. Goodwin, K. Iken, A.C. Marques, P. Miloslavich, M. Ostrowski, W. Turner, E.P. Achterberg, T. Barry, O. Defeo, G. Bigatti, L.A. Henry, B. Ramiro-Sánchez, P. Durán, T. Morato, J.M. Roberts, A. García-Alegre, M.S. Cuadrado, B. Murton, Global observational needs and resources for marine biodiversity, Front. Mar. Sci. 6 (367) (2019). 〈https://www.frontiersin.org/article/10.3389/fmars.2019.00367〉.

[12] B. Mackenzie, L. Celliers, L.P.F. Assad, J.J. Heymans, N. Rome, J. Thomas, C. Anderson, J. Behrens, M. Calverley, K. Desai, P.M. DiGiacomo, S. Djavidnia, F. dos Santos, D. Eparkhina, J. Ferrari, C. Hanly, B. Houtman, G. Jeans, L. Landau, K. Larkin, D. Legler, P.Y. Le Traon, E. Lindstrom, D. Loosley, G. Nolan, G. Petihakis, J. Pellegrini, Z. Roberts, J.R. Siddorn, E. Smail, I. Sousa-Pinto, E. Terrill, The role of stakeholders in creating societal value from coastal and ocean observations, Front. Mar. Sci. 6 (137) (2019), https://doi.org/10.3389/ fmars.2019.00137.

[13] P. Miloslavich, N.J. Bax, S.E. Simmons, E. Klein, W. Appeltans, O. AburtoOropeza, M. Andersen Garcia, S.D. Batten, L. Benedetti-Cecchi, D.M. Checkley, S. Chiba, J.E. Duffy, D.C. Dunn, A. Fischer, J. Gunn, R. Kudela, F. Marsac, F. 
E. Muller-Karger, D. Obura, Y.J. Shin, Essential ocean variables for global sustained observations of biodiversity and ecosystem changes, Glob. Change Biol. 24 (6) (2018) 2416-2433, https://doi.org/10.1111/gcb.14108.

[14] GOOS, The Global Ocean Observing System 2030 Strategy. IOC, Paris, 2019, IOC Brochure 2019-5 (IOC/BRO/2019/5 rev.2), GOOS Report No.239, 2019.

[15] T. Tanhua, A. McCurdy, A. Fischer, W. Appeltans, N. Bax, K. Currie, et al., What we have learned from the framework for ocean observing: evolution of the global ocean observing system, Front. Mar. Sci. 6 (AUG) (2019), https://doi.org/ 10.3389/fmars.2019.00471.

[16] J. Pearlman, M. Bushnell, L. Coppola, J. Karstensen, P.L. Buttigieg, F. Pearlman, P. Simpson, M. Barbier, F.E. Muller-Karger, C. Munoz-Mas, P. Pissierssens, C. Chandler, J. Hermes, E. Heslop, R. Jenkyns, E.P. Achterberg, M. Bensi, H. C. Bittig, J. Blandin, J. Bosch, B. Bourles, R. Bozzano, J. Buck, E.F. Burger, D. Cano, V. Cardin, M.C. Llorens, A. Cianca, H. Chen, C. Cusack, E. Delory, R. Garello, G. Giovanetti, V. Harscoat, S. Hartman, R. Heitsenrether, S. Jirka, A. Lara-Lopez, N. Lantéri, A. Leadbetter, G. Manzella, J. Maso, A. McCurdy, E. Moussat, M. Ntoumas, S. Pensieri, G. Petihakis, N. Pinardi, S. Pouliquen, R. Przeslawski, N.P. Roden, J. Silke, M.N. Tamburri, H. Tang, T. Tanhua, M. Telszewski, P. Testor, J. Thomas, C. Waldmann, F. Whoriskey, Evolving and sustaining ocean best practices and standards for the next decade, Front. Mar. Sci. 6 (277) (2019), https://doi.org/10.3389/fmars.2019.00277.

[17] A. Benson, C.M. Brooks, G. Canonico, E. Duffy, F. Muller-Karger, H.M. Sosik, P. Miloslavich, E. Klein, Integrated observations and informatics improve understanding of changing marine ecosystems, Front. Mar. Sci. 5 (428) (2018), https://doi.org/10.3389/fmars.2018.00428.

[18] M.D. Wilkinson, M. Dumontier, I.J. Aalbersberg, G. Appleton, M. Axton, A. Baak, N. Blomberg, J.W. Boiten, L.B. da Silva Santos, P.E. Bourne, J. Bouwman, A. J. Brookes, T. Clark, M. Crosas, I. Dillo, O. Dumon, S. Edmunds, C.T. Evelo, R. Finkers, A. Gonzalez-Beltran, A.J. Gray, P. Groth, C. Goble, J.S. Grethe, J. Heringa, P.A. 't Hoen, R. Hooft, T. Kuhn, R. Kok, J. Kok, S.J. Lusher, M. E. Martone, A. Mons, A.L. Packer, B. Persson, P. Rocca-Serra, M. Roos, R. van Schaik, S.A. Sansone, E. Schultes, T. Sengstag, T. Slater, G. Strawn, M.A. Swertz, M. Thompson, J. van der Lei, E. van Mulligen, J. Velterop, A. Waagmeester, P. Wittenburg, K. Wolstencroft, J. Zhao, B. Mons, The FAIR guiding principles for scientific data management and stewardship, Sci. Data 3 (2016), 160018, https:// doi.org/10.1038/sdata.2016.18.

[19] E. Boss, A. Waite, F. Muller-Karger, H. Yamazaki, R. Wanninkhof, J. Uitz, S. Thomalla, H. Sosik, B. Sloyan, A. Richardson, P. Miloslavich, J. Karstensen, G. Grégori, K. Fennel, H. Claustre, M. Cornejo, I. Berman-Frank, S. Batten, S. Acinas, Beyond chlorophyll fluorescence: the time is right to expand biologica measurements in ocean observing programs, Limnol. Oceanogr. Bull. 27 (2018) 89-90, https://doi.org/10.1002/lob.10243.

[20] F. Lombard, E. Boss, A.M. Waite, M. Vogt, J. Uitz, L. Stemmann, H.M. Sosik, J. Schulz, J.B. Romagnan, M. Picheral, J. Pearlman, M.D. Ohman, B. Niehoff, K. O. Möller, P. Miloslavich, A. Lara-Lpez, R. Kudela, R.M. Lopes, R. Kiko, L. KarpBoss, J.S. Jaffe, M.H. Iversen, J.O. Irisson, K. Fennel, H. Hauss, L. Guidi, G. Gorsky, S. Giering, P. Gaube, S. Gallager, G. Dubelaar, R.K. Cowen, F. Carlotti, C. Briseño-Avena, L. Berline, K. Benoit-Bird, N. Bax, S. Batten, S.D. Ayata, L. F. Artigas, W. Appeltans, Globally consistent quantitative observations of planktonic ecosystems, Front. Mar. Sci. 6 (196) (2019).

[21] SCOR WG 154, Recommendations for plankton measurements on the GO-SHIP program with relevance to other sea-going expeditions. SCOR Working Group 154 GO-SHIP Report, Sci. Comm. Ocean. Res. (2020) 70, https://doi.org/ 10.25607/OBP-718.

[22] L. Pendleton, K. Evans, M. Visbeck, Opinion: We need a global movement to transform ocean science for a better world, Proc. Natl. Acad. Sci. 117 (18) (2020) 9652-9655, https://doi.org/10.1073/pnas.2005485117.

[23] A. Brett, J. Leape, M. Abbott, H. Sakaguchi, L. Cao, K. Chand, Y. Golbuu, T. J. Martin, J. Mayorga, M.S. Myksvoll, Ocean data need a sea change to help navigate the warming world, Nature 582 (2020) 181-183, https://doi.org/ 10.1038/d41586-020-01668-z.

[24] F.E. Muller-Karger, P. Miloslavich, N. Bax, S. Simmons, M.J. Costello, I.S. Pinto, et al., Advancing marine biological observations and data requirements of the complementary Essential Ocean Variables (EOVs) and Essential Biodiversity Variables (EBVs) frameworks, Front. Mar. Sci. 5 (JUN) (2018), https://doi.org/ 10.3389/fmars.2018.00211.

[25] J.O. Schmidt, S.J. Bograd, H. Arrizabalaga, J.L. Azevedo, S.J. Barbeaux, J. A. Barth, T. Boyer, S. Brodie, J.J. Cárdenas, S. Cross, J.N. Druon, A. Fransson, J. Hartog, E.L. Hazen, A. Hobday, M. Jacox, J. Karstensen, S. Kupschus, J. Lopez, L. Madureira, J.E. Martinelli Filho, P. Miloslavich, C.P. Santos, K. Scales, S. Speich, M.B. Sullivan, A. Szoboszlai, D. Tommasi, D. Wallace, S. Zador, P. A. Zawislak, Future ocean observations to connect climate, fisheries and marine ecosystems, Front. Mar. Sci. 6 (2019), https://doi.org/10.3389/ fmars.2019.00550.

[26] P.G. Falkowski, R.T. Barber, V. Smetacek, Biogeochemical controls and feedbacks on ocean primary production, Science 281 (200) (1998) 200-207, https://doi. org/10.1126/science.281.5374.200.

[27] J. Beardall, S. Slobodanka, S. Larsen, 2009, Living in a high CO2 world: impacts of global climate change on marine phytoplankton, Plant Ecology \& Diversity, 2: 2, 2009: pp. 191-205, DOI: 10.1080/17550870903271363.

[28] G.E.P. Murphy, T.N. Romanuk, B. Worm, Cascading effects of climate change on plankton community structure, Ecol. Evol. 10 (4) (2020) 2170-2181, https://doi org/10.1002/ece3.6055.

[29] D. Breitburg, L.A. Levin, A. Oschlies, M. Grégoire, F.P. Chavez, D.J. Conley, V. Garçon, D. Gilbert, D. Gutiérrez, K. Isensee, G.S. Jacinto, K.E. Limburg, I. Montes, S. Naqvi, G.C. Pitcher, N.N. Rabalais, M.R. Roman, K.A. Rose, B.
A. Seibel, M. Telszewski, M. Yasuhara, J. Zhang, Declining oxygen in the global ocean and coastal waters, Science 359 (2018), https://doi.org/10.1126/science. aam7240 eaam7240.

[30] World Economic Forum, 2018. 〈https://www.weforum.org/agenda/2018/01/ dead-zones-in-our-oceans-have-increased-dramatically-since-1950-and-we-re-toblame/ $\rangle$.

[31] T. Platt, C. Fuentes-Yaco, K. Frank, Spring algal bloom and larval fish survival, Nature 423 (2003) 398-399.

[32] R.G. Asch, C.A. Stock, J.L. Sarmiento, Climate change impacts on mismatches between phytoplankton blooms and fish spawning phenology, Glob. Change Biol. 25 (2019) 2544-2559, https://doi.org/10.1111/gcb.14650.

[33] D. Grémillet, T. Boulinier, Spatial ecology and conservation of seabirds facing global climate change: a review, Mar. Ecol. Prog. Ser. 391 (2009) 121-137, https://doi.org/10.3354/meps08212.

[34] D. Pendleton, A. Pershing, M. Brown, C. Mayo, R. Kenney, N. Record, T. Cole, Regional-scale mean copepod concentration indicates relative abundance of North Atlantic right whales, Mar. Ecol. Prog. Ser. 378 (2009) 211-225, https:// doi.org/10.3354/meps07832.

[35] FAO, Manual on the Production and Use of Live Food for Aquaculture. FAO Fisheries Technical Paper 361. Edited by Patrick Lavens and Patrick Sorgeloos, 1996. ISBN 92-5-103934-8. 〈http://www.fao.org/3/W3732E/w3732e00.htm〉.

[36] C.R. Anderson, E. Berdalet, R.M. Kudela, C.K. Cusack, J. Silke, E. O'Rourke, et al., Scaling up from regional case studies to a global harmful algal bloom observing system, Front. Mar. Sci. 6 (250) (2019). DOI=10.3389/fmars.2019.00250 (2019).

[37] D. Pauly, D. Zeller, Catch reconstructions reveal that global marine fisheries catches are higher than reported and declining, Nat. Commun. 7 (10244) (2016) 10244.

[38] D. Pauly, D. Zeller, M.L.D. Palomares (Editors), Sea Around Us Concepts, Design and Data (seaaroundus.org), 2020.

[39] R.D. Stuart-Smith, C.J. Brown, D.M. Ceccarelli, G.J. Edgar, Ecosystem restructuring along the Great Barrier Reef following mass coral bleaching, Nature 560 (2018) 92-96, https://doi.org/10.1038/s41586-018-0359-9.

[40] F.J. Heather, J.L. Blanchard, G.J. Edgar, R. Trebilco, R.D. Stuart-Smith, 'Globally consistent reef size spectra integrating fishes and invertebrates', Ecol. Lett. 24 (3) (2021) 572-579, https://doi.org/10.1111/ele.13661.

[41] E.M.A. Strain, G.J. Edgar, D. Ceccarelli, R.D. Stuart-Smith, G.R. Hosack, R. $\mathrm{J}$. Thomson, A global assessment of the direct and indirect benefits of marine protected areas for coral reef conservation, Divers. Distrib. (2018), https://doi. org/10.1111/ddi.12838.

[42] D. Checkley, Y. Shin, Essential Ocean Variables (EOV) for Biology and Ecosystems: Fish abundance and distribution. Last updated Version 2017.02.07, 2017. 〈https://www.goosocean.org/components/com_oe/oe.php? task=download\&id $=38714 \&$ version $=1.0 \&$ lang $=1 \&$ format $=1\rangle$.

[43] C. Mazzoldi, G. Bearzi, C. Brito, I. Carvalho, E. Desiderà, L. Endrizzi, From sea monsters to charismatic megafauna: changes in perception and use of large marine animals, PLOS One 14 (2019), 0226810, https://doi.org/10.1371/ journal.pone.0226810.

[44] G.M.S. Vianna, M.G. Meekan, A.A. Rogers, M.E. Kragt, J.M. Alin, J. S. Zimmerhackel, Shark-diving tourism as a financing mechanism for shark conservation strategies in Malaysia, Mar. Policy 94 (2018) 220-226, https://doi. org/10.1016/j.marpol.2018.05.008.

[45] A.M.M. Sequeira, G.C. Hays, D.W. Sims, V.M. Eguíluz, J.P. Rodríguez, M. R. Heupel, R. Harcourt, H. Calich, N. Queiroz, D.P. Costa, J. Fernández-Gracia, L. C. Ferreira, S.D. Goldsworthy, M.A. Hindell, M.A. Lea, M.G. Meekan, A. M. Pagano, S.A. Shaffer, J. Reisser, M. Thums, M. Weise, C.M. Duarte, Overhauling ocean spatial planning to improve marine megafauna conservation, Front. Mar. Sci. 6 (2019).

[46] R. Harcourt, A.M.M. Sequeira, X. Zhang, F. Roquet, K. Komatsu, M. Heupel, C. McMahon, F. Whoriskey, M. Meekan, G. Carroll, S. Brodie, C. Simpfendorfer, M. Hindell, I. Jonsen, D.P. Costa, B. Block, M. Muelbert, B. Woodward, M. Weise, K. Aarestrup, M. Biuw, L. Boehme, S.J. Bograd, D. Cazau, J.B. Charrassin, S. J. Cooke, P. Cowley, P. de Bruyn, T. Jeanniard du Dot, C. Duarte, V.M. Eguíluz, L. C. Ferreira, J. Fernández-Gracia, K. Goetz, Y. Goto, C. Guinet, M. Hammill, G. C. Hays, E.L. Hazen, L.A. Hückstädt, C. Huveneers, S. Iverson, S.A. Jaaman, K. Kittiwattanawong, K.M. Kovacs, C. Lydersen, T. Moltmann, M. Naruoka, L. Phillips, B. Picard, N. Queiroz, G. Reverdin, K. Sato, D.W. Sims, E.B. Thorstad, M. Thums, A.M. Treasure, A.W. Trites, G.D. Williams, Y. Yonehara, M.A. Fedak, Animal-borne telemetry: an integral component of the ocean observing toolkit, Front. Mar. Sci. 6 (2019).

[47] A.M.M. Sequeira, M. O'Toole, T.R. Keates, L.H. McDonnell, C.D. Braun, X. Hoenner, F. Jaine, I.D. Jonsen, P. Newman, J. Pye, S.J. Bograd, G.C. Hays, E. L. Hazen, M. Holland, V.M. Tsontos, C. Blight, F. Cagnacci, S.C. Davidson, H. Dettki, C.M. Duarte, D.C. Dunn, V.M. Eguíluz, M. Fedak, A.C. Gleiss, N. Hammerschlag, M.A. Hindell, K. Holland, I. Janekovic, M.K. McKinzie, M. Muelbert, C. Pattiaratchi, C. Rutz, D.W. Sims, S.E. Simmons, B. Townsend, F. Whoriskey, B. Woodward, D.P. Costa, M.R. Heupel, C.R. McMahon, R. Harcourt, M. Weise, A standardisation framework for bio-logging data to advance ecological research and conservation, Methods Ecol. Evol. 12 (2021) 996-1007, https://doi.org/10.1111/2041-210X.13593.

[48] P.L. Tyack, Developing an essential ocean variable for the acoustic environment, J. Acoust. Soc. Am. 141 (2017) 3525, https://doi.org/10.1121/1.4987432.

[49] T.A. Mooney, L. Di Iorio, M. Lammers, T.-H. Lin, S.L. Nedelec, M. Parsons, C. Radford, E. Urban, J. Stanley, Listening forward: approaching marine biodiversity assessments using acoustic methods, R. Soc. Open Sci. 7 (2020), 201287, https://doi.org/10.1098/rsos.201287. 
[50] A. Monczak, B. McKinney, C. Mueller, E.W. Montie, What's all that racket! Soundscapes, phenology, and biodiversity in estuaries, PLoS ONE 15 (9) (2020), 0236874, https://doi.org/10.1371/journal.pone.0236874.

[51] N. Pieretti, M. Lo Martire, A. Farina, R. Danovaro, Marine soundscape as an additional biodiversity monitoring tool: a case study from the Adriatic Sea (Mediterranean Sea), Ecol. Indic. 83 (2017) 13-20, https://doi.org/10.1016/j. ecolind.2017.07.011.

[52] C.M. Duarte, L. Chapuis, S.P. Collin, D.P. Costa, R.P. Devassy, V.M. Eguiluz, C. Erbe, T. Gordon, B.S. Halpern, H.R. Harding, M.N. Havlik, M. Meekan, N. D. Merchant, J.L. Miksis-Olds, M. Parsons, M. Predragovic, A.N. Radford, C. A. Radford, S.D. Simpson, H. Slabbekoorn, E. Staaterman, I.C. Van Opzeeland, J. Winderen, X. Zhang, F. Juanes, The soundscape of the Anthropocene ocean, Science 371 (2021), https://doi.org/10.1126/science.aba4658.

[53] I.T. Roca, I.V. Opzeeland, Using acoustic metrics to characterize underwater acoustic biodiversity in the Southern Ocean, in: Remote Sens. Ecol. Conserv., 6 , 2020, pp. 262-273. 〈https://zslpublications.onlinelibrary.wiley.com/doi/pdfdir ect/10.1002/rse2.129).

[54] L.A. Levin, B.J. Bett, A.R. Gates, P. Heimbach, B.M. Howe, F. Janssen, A. McCurdy, H.A. Ruhl, P. Snelgrove, K.I. Stocks, D. Bailey, S. BaumannPickering, C. Beaverson, M.C. Benfield, D.J. Booth, M. Carreiro-Silva, A. Colaço, M.C. Eblé, A.M. Fowler, K.M. Gjerde, D. Jones, K. Katsumata, D. Kelley, N. Le Bris, A.P. Leonardi, F. Lejzerowicz, P.I. Macreadie, D. McLean, F. Meitz, T. Morato, A. Netburn, J. Pawlowski, C.R. Smith, S. Sun, H. Uchida, M.F. Vardaro, R. Venkatesan, R.A. Weller, Global observing needs in the deep ocean, Front. Mar Sci. 6 (241) (2019), https://doi.org/10.3389/fmars.2019.00241.

[55] K.J. Benoit-Bird, L.L. Gareth, Ecological insights from pelagic habitats acquired using active acoustic techniques, Annu. Rev. Mar. Sci. 8 (1) (2016) 463-490, https://doi.org/10.1146/annurev-marine-122414-034001.

[56] K.J. Benoit-Bird, T. Patrick Welch, C.M. Waluk, J.A. Barth, I. Wangen, P. McGill, et al., Equipping an underwater glider with a new echosounder to explore ocean ecosystems, Limnol. Oceano Methods 16 (2018) 734-749, https://doi.org/ 10.1002/lom3.10278.

[57] B. Gottesman, J. Sprague, D. Kushner, K. Bellisario, D. Savage, M. McKenna, D. L. Conlin, E. DiDonato, M.J. Barkaszi, M.B. Halvorsen, B.C. Pijanowski, Soundscapes indicate kelp forest condition, Mar. Ecol. Prog. Ser. 654 (2020) 35-52, https://doi.org/10.3354/meps13512.

[58] J.P. Ryan, J.E. Joseph, T. Margolina, L.T. Hatch, A. Azzara, A. Reyes, B. L. Southall, A. DeVogelaere, L.E. Peavey Reeves, Y. Zhang, D.E. Cline, B. Jones, P. McGill, S. Baumann-Pickering, A.K. Stimpert, Reduction of low-frequency vessel noise in monterey bay national marine sanctuary during the COVID-19 pandemic, Front. Mar. Sci. 8 (2021), https://doi.org/10.3389/ fmars.2021.656566.

[59] B.M. Howe, J. Miksis-Olds, E. Rehm, H. Sagen, P.F. Worcester, G. Haralabus, Observing the oceans acoustically, Front. Mar. Sci. 6 (426) (2019), https://doi. org/10.3389/fmars.2019.00426.

[60] G. Lamarche, X. Lurton, Recommendations for improved and coherent acquisition and processing of backscatter data from seafloor-mapping sonars, Mar. Geophys Res. 39 (2018) 5-22, https://doi.org/10.1007/s11001-017-9315-6.

[61] L. Mayer, M. Jakobsson, G. Allen, B. Dorschel, R. Falconer, V. Ferrini, G. Lamarche, H. Snaith, P. Weatherall, The Nippon Foundation-GEBCO Seabed 2030 project: the quest to see the world's oceans completely mapped by 2030 , Geosciences 8 (2) (2018) 63.

[62] J.E. Duffy, L. Benedetti-Cecchi, J. Trinanes, F.E. Muller-Karger, R. Ambo-Rappe, C. Boström, A.H. Buschmann, J. Byrnes, R.G. Coles, J. Creed, L.C. CullenUnsworth, G. Diaz-Pulido, C.M. Duarte, G.J. Edgar, M. Fortes, G. Goni, C. Hu, X. Huang, C.L. Hurd, C. Johnson, B. Konar, D. Krause-Jensen, K. Krumhansl, P. Macreadie, H. Marsh, L.J. McKenzie, N. Mieszkowska, P. Miloslavich, E. Montes, M. Nakaoka, K.M. Norderhaug, L.M. Norlund, R.J. Orth, A. Prathep, N. F. Putman, J. Samper-Villarreal, E.A. Serrao, F. Short, I.S. Pinto, P. Steinberg, R. Stuart-Smith, R. Unsworth, M. van Keulen, B.I. van Tussenbroek, M. Wang, M. Waycott, L.V. Weatherdon, T. Wernberg, S.M. Yaakub, Toward a coordinated global observing system for seagrasses and marine macroalgae, Front. Mar. Sci. 6 (2019), https://doi.org/10.3389/fmars.2019.00317.

[63] United Nations Environment Programme. Emissions Gap Report 2020. Nairobi, 2020.

[64] R. Costanza, O. Pérez-Maqueo, M.L. Martinez, P. Sutton, S.J. Anderson, K. Mulder, The value of coastal wetlands for hurricane protection, AMBIO: A J. Hum. Environ. 37 (4) (2008) 241-248, https://doi.org/10.1579/0044-7447 (2008)37[241:TVOCWF]2.0.CO;2.

[65] T. Wernberg, K. Krumhansl, K. Filbee-Dexter, M.F. Pedersen, Status and trends for the world's kelp forests, in: C. Sheppard (Ed.), World Seas: An Environmental Evaluation., Elsevier, Amsterdam, 2019, pp. 57-78.

[66] J. Dugan, J.E. Maciel, et al., Marine Macrophytes, Excelic Press, Lewes, DE, 2019.

[67] A. Ortega, N.R. Geraldi, I. Alam, A.A. Kamau, S.G. Acinas, R. Logares, J.M. Gasol, R. Massana, D. Krause-Jensen, C.M. Duarte, Important contribution of macroalgae to oceanic carbon sequestration, Nat. Geosci. 12 (2019) 748-754, https://doi.org/10.1038/s41561-019-0421-8.

[68] M. Wang, C. Hu, B.B. Barnes, G. Mitchum, B. Lapointe, J.P. Montoya, The great Atlantic Sargassum belt, Science 365 (2019) 83-87.

[69] E.M. Johns, R. Lumpkin, N.F. Putman, R.H. Smith, F.E. Muller-Karger, D. T. Rueda-Roa, et al., The establishment of a pelagic Sargassum population in the tropical Atlantic: biological consequences of a basin-scale long distance dispersa event, Prog. Oceanogr. (2020), https://doi.org/10.1016/j.pocean.2020.102269.

[70] O. Hoegh-Guldberg, Reviving the Ocean Economy: the Case for Action - 2015, WWF International, Gland, Geneva, 2015, p. 60.
[71] D.O. Obura, G. Aeby, N. Amornthammarong, W. Appeltans, N. Bax, J. Bishop, R. E. Brainard, S. Chan, P. Fletcher, T. Gordon, L. Gramer, M. Gudka, J. Halas, J. Hendee, G. Hodgson, D. Huang, M. Jankulak, A. Jones, T. Kimura, J. Levy, P. Miloslavich, L.M. Chou, F. Muller-Karger, K. Osuka, M. Samoilys, S.D. Simpson, K. Tun, S. Wongbusarakum, Coral reef monitoring, reef assessment technologies, and ecosystem-based management, Front. Mar. Sci. 6 (580) (2019), https://doi. org/10.3389/fmars.2019.00580.

[72] S.A. Pomponi, A. Jevitt, J. Patel, M.C. Diaz, Sponge hybridomas: applications and implications, Integr. Comp. Biol. 53 (2013) 524-530, https://doi.org/10.1093/ icb/ict032.

[73] D. Sipkema, R. Osinga, W. Schatton, D. Mendola, J. Tramper, R.H. Wijffels, Largescale production of pharmaceuticals by marine sponges: sea, cell, or synthesis? Biotechnol. Bioeng. 90 (2005) 201-222, https://doi.org/10.1002/bit.20404.

[74] H. Hao, W. Lei, O. Danyun, L. Weiwen, K. Fangfang, L. Cai, H. Xuebao, A. Lina, W. Weobo, A preliminary evaluation of some elements for designation of preservation and impact reference zones in deep sea in the Clarion-Clipperton Zone: a case study of the China ocean mineral resources association contract area, Ocean Coast. Manag. 188 (2020), 105135.

[75] J. Williams, F. Althaus, K. Maguire, M. Green, C. Untiedt, P. Alderslade, et al., The fate of deep-sea coral reefs on seamounts in a fishery-seascape: what are the impacts, what remains, and what is protected? Front. Mar. Sci. 7 (798) (2020) https://doi.org/10.3389/fmars.2020.567002.

[76] K.L. Howell, A. Hilário, A.L. Allcock, D.M. Bailey, M. Baker, M.R. Clark, A. Colaço, J. Copley, E.E. Cordes, R. Danovaro, A. Dissanayake, E. Escobar, P. Esquete, A.J. Gallagher, A.R. Gates, S.M. Gaudron, C.R. German, K.M. Gjerde, N.D. Higgs, N. Le Bris, L.A. Levin, E. Manea, C. McClain, L. Menot, N.C. Mestre, A. Metaxas, R.J. Milligan, A. Muthumbi, B.E. Narayanaswamy, S.P. Ramalho, E. Ramirez-Llodra, L.M. Robson, A.D. Rogers, J. Sellanes, J.D. Sigwart, K. Sink, P. Snelgrove, P.V. Stefanoudis, P.Y. Sumida, M.L. Taylor, A.R. Thurber, R. P. Vieira, H.K. Watanabe, L.C. Woodall, J.R. Xavier, A Blueprint for an Inclusive, Global Deep-Sea Ocean Decade Field Program, Front. Mar. Sci. 7 (2020), https:// doi.org/10.3389/fmars.2020.584861.

[77] Ocean Decade Actions, Announcement of the results of the first endorsed Decade Actions following Call for Decade Actions No. 01/2020, . 〈https://www. oceandecade.org/resource/166/Announcement-of-the-results-of-the-firstendorsed-Decade-Actions-following-Call-for-Decade-Actions-No-012020 $\rangle$.

[78] M.T. Kavanaugh, M.J. Oliver, F.P. Chavez, R.M. Letelier, F.E. Muller-Karger, S. C. Doney, Seascapes as a new vernacular for pelagic ocean monitoring, management and conservation!Abstract, ICES J. Mar. Sci. 73 (2016) 1839-1850, https://doi.org/10.1093/icesjms/fsw086.

[79] E. Montes, A. Djurhuus, F.E. Muller-Karger, D. Otis, C.R. Kelble, M.T. Kavanaugh, Dynamic satellite seascapes as a biogeographic framework for understanding phytoplankton assemblages in the florida keys national marine sanctuary, United States!Data_Sheet_1.pdf!Image_1.JPEG!Image_2.JPEG!Image_3.JPEG!Image_4. JPEG, Front. Mar. Sci. 7 (2020), https://doi.org/10.3389/fmars.2020.00575.

[80] R. Sayre, D. Wright, S. Breyer, K. Butler, K. Van Graafeiland, M. Costello, P. Harris, K. Goodin, J. Guinotte, Z. Basher, M. Kavanaugh, P. Halpin, M. Monaco, N. Cressie, P. Aniello, C. Frye, D. Stephens, A three- dimensional mapping of the ocean based on environmental data, Oceanography 30 (1) (2017) 90-103, https://doi.org/10.5670/oceanog.2017.116.

[81] M.J. McCarthy, K.E. Colna, M.M. El-Mezayen, A.E. Laureano-Rosario, P. MéndezLázaro, D.B. Otis, G. Toro-Farmer, M. Vega-Rodriguez, F.E. Muller-Karger, Satellite remote sensing for coastal management: a review of successful applications, Environ. Manag. 60 (2017) 323-339, https://doi.org/10.1007/ s00267-017-0880-x.

[82] F.E. Muller-Karger, E. Hestir, C. Ade, K. Turpie, D.A. Roberts, D. Siegel, R. J. Miller, D. Humm, N. Izenberg, M. Keller, F. Morgan, R. Frouin, A.G. Dekker, R. Gardner, J. Goodman, B. Schaeffer, B.A. Franz, N. Pahlevan, A.G. Mannino, J. A. Concha, S.G. Ackleson, K.C. Cavanaugh, A. Romanou, M. Tzortziou, E.S. Boss, R. Pavlick, A. Freeman, C.S. Rousseaux, J. Dunne, M.C. Long, E. Klein, G. A. McKinley, J. Goes, R. Letelier, M. Kavanaugh, M. Roffer, A. Bracher, K. R. Arrigo, H. Dierssen, X. Zhang, F.W. Davis, B. Best, R. Guralnick, J. Moisan, H. M. Sosik, R. Kudela, C.B. Mouw, A.H. Barnard, S. Palacios, C. Roesler, E. G. Drakou, W. Appeltans, W. Jetz, Satellite sensor requirements for monitoring essential bio6diversity variables of coastal ecosystems, Ecol. Appl. 28 (2018) 749-760, https://doi.org/10.1002/eap.1682.

[83] A. Bracher, H.A. Bouman, R.J.W. Brewin, A. Bricaud, V. Brotas, A.M. Ciotti, et al., Obtaining phytoplankton diversity from ocean color: a scientific roadmap for future, Dev., Front. Mar. Sci. 4 (55) (2017), https://doi.org/10.3389/ fmars.2017.00055.

[84] M.J. Behrenfeld, P. Gaube, A. Della Penna, R.T. O'malley, W.J. Burt, Y. Hu, P. S. Bontempi, D.K. Steinberg, E.S. Boss, D.A. Siegel, C.A. Hostetler, P.D. Tortell, S. C. Doney, Global satellite-observed daily vertical migrations of ocean animals, Nature 576 (2019) 257-261, https://doi.org/10.1038/s41586-019-1796-9.

[85] H. Loisel, L. Duforet, D. Dessailly, M. Chami, P. Dubuisson, Investigation of the variations in the water leaving polarized reflectance from the POLDER satellite data over two biogeochemical contrasted oceanic areas, Opt. Express 16 (2008) 12905-12918, https://doi.org/10.1364/OE.16.012905.

[86] A. Djurhuus, C.J. Closek, R.P. Kelly, K.J. Pitz, R.P. Michisaki, H.A. Starks, K. R. Walz, E.A. Andruszkiewicz, E. Olesin, K. Hubbard, E. Montes, D. Otis, F. E. Muller-Karger, F.P. Chavez, A.B. Boehm, M. Breitbart, Environmental DNA reveals seasonal shifts and potential interactions in a marine community, Nat. Commun. 11 (254) (2020) 254, https://doi.org/10.1038/s41467-019-14105-1.

[87] K.D. Goodwin, F.E. Muller-Karger, A. Djurhuus, L.Z. Allen, A.E. Allen, J.P. McCrow, G. Canonico-Hyde, Chapter 32. Molecular Approaches for an Operational Marine Biodiversity Observation Network. In: World Seas: An 
Environmental Evaluation, Vol. III: Ecological Issues and Environmental Impacts. 2nd Edition. Charles Sheppard (editor), 2019. 〈https://scholarcommons.usf.edu/ msc_facpub/630 $>$.

[88] P. Yilmaz, R. Kottmann, D. Field, R. Knight, J.R. Cole, L. Amaral-Zettler, J. A. Gilbert, I. Karsch-Mizrachi, A. Johnston, G. Cochrane, R. Vaughan, C. Hunter, J. Park, N. Morrison, P. Rocca-Serra, P. Sterk, M. Arumugam, M. Bailey, L. Baumgartner, B.W. Birren, M.J. Blaser, V. Bonazzi, T. Booth, P. Bork, F. D. Bushman, P.L. Buttigieg, P.S. Chain, E. Charlson, E.K. Costello, H. Huot-Creasy, P. Dawyndt, T. DeSantis, N. Fierer, J.A. Fuhrman, R.E. Gallery, D. Gevers, R. A. Gibbs, I. San Gil, A. Gonzalez, J.I. Gordon, R. Guralnick, W. Hankeln, S. Highlander, P. Hugenholtz, J. Jansson, A.L. Kau, S.T. Kelley, J. Kennedy, D. Knights, O. Koren, J. Kuczynski, N. Kyrpides, R. Larsen, C.L. Lauber, T. Legg, R. E. Ley, C.A. Lozupone, W. Ludwig, D. Lyons, E. Maguire, B.A. Methé, F. Meyer, B. Muegge, S. Nakielny, K.E. Nelson, D. Nemergut, J.D. Neufeld, L.K. Newbold, A. E. Oliver, N.R. Pace, G. Palanisamy, J. Peplies, J. Petrosino, L. Proctor, E. Pruesse, C. Quast, J. Raes, S. Ratnasingham, J. Ravel, D.A. Relman, S. Assunta-Sansone, P. D. Schloss, L. Schriml, R. Sinha, M.I. Smith, E. Sodergren, A. Spo, J. Stombaugh, J. M. Tiedje, D.V. Ward, G.M. Weinstock, D. Wendel, O. White, A. Whiteley, A. Wilke, J.R. Wortman, T. Yatsunenko, F.O. Glöckner, Minimum information about a marker gene sequence (MIMARKS) and minimum information about any (x) sequence (MIxS) specifications, Nat. Biotechnol. 29 (5) (2011) 415-420.

[89] R.M. Hillary, M.V. Bravington, T.A. Patterson, P. Grewe, R. Bradford, P. Feutry, R. Gunasekera, V. Peddemors, J. Werry, M.P. Francis, C. Duffy, B.D. Bruce, Genetic relatedness reveals total population size of white sharks in eastern Australia and New Zealand, Sci. Rep. 8 (2018) 2661.

[90] J. Leape, M. Abbott, H. Sakaguchi, et al., Technology, Data and New Models for Sustainably Managing Ocean Resources, World Resources Institute, Washington, DC, 2020. 〈https://oceanpanel.org/sites/default/files/2020-01/19_HLP_BP6_V4. pdf $\rangle$.

[91] D. Stammer, M. Balmaseda, P. Heimbach, A. Köhl, A. Weaver, Ocean data assimilation in support of climate applications: status and perspectives, Annu. Rev. Mar. Sci. 8 (2016) 491-518, https://doi.org/10.1146/annurev-marine122414-034113.

[92] K. Fennel, M. Gehlen, P. Brasseur, C.W. Brown, S. Ciavatta, G. Cossarini, A. Crise C.A. Edwards, D. Ford, M. Friedrichs, M. Gregoire, E. Jones, H.C. Kim, J. Lamouroux, R. Murtugudde, C. Perruche, Advancing marine biogeochemical and ecosystem reanalyses and forecasts as tools for monitoring and managing ecosystem health, Front. Mar. Sci. 6 (89) (2019), https://doi.org/10.3389/ fmars.2019.00089.

[93] H. Moustahfid, L. Hendrickson, A. Arkhipkin, G. Pierce, H. Kidokoro, U. Markaida, et al., Ecological-fishery forecasting of squid stock dynamics under climate variability and change: review, Challenges, and Recommendations, Rev. Fish. Sci. Aquacult. 28 (2) (2021), https://doi.org/10.1080/ 23308249.2020.1864720.

[94] M.R. Payne, A.J. Hobday, B.R. MacKenzie, D. Tommasi, D.P. Dempsey, S.M. M. Fässler, S. Fässler, A.C. Haynie, R. Ji, G. Liu, P.D. Lynch, D. Matei, A. K. Miesner, K.E. Mills, K.O. Strand, E. Villarino, Lessons from the first generation of marine ecological forecast products, Front Mar. Sci. 4 (289) (2017), https:// doi.org/10.3389/fmars.2017.00289.

[95] E. Olsen, I.C. Kaplan, C. Ainsworth, G. Fay, S. Gaichas, R. Gamble, et al., Ocean futures under ocean acidification, marine protection, and changing fishing pressures explored using a worldwide suite of ecosystem models, Front. Mar. Sci. 5 (64) (2018), https://doi.org/10.3389/fmars.2018.00064.

[96] W.L. Geary, M. Bode, T.S. Doherty, E.A. Fulton, D.G. Nimmo, A.I.T. Tulloch, V. Tulloch, E.G. Ritchie, A guide to ecosystem models and their environmental applications, Nat. Ecol. Evol. 4 (2020) 1459-1471, https://doi.org/10.1038/ s41559-020-01298-8.

[97] C.R. Anderson, R.M. Kudela, M. Kahru, Y. Chao, L.K. Rosenfeld, F.L. Bahr, D. M. Anderson, T.A. Norris, Initial skill assessment of the California harmful algae risk mapping (C-HARM) system, Harmful Algae 59 (2016) 1-18, https://doi.org/ 10.1016/j.hal.2016.08.006.

[98] E.L. Hazen, K.L. Scales, S.M. Maxwell, D.K. Briscoe, H. Welch, S.J. Bograd, H. Bailey, S.R. Benson, T. Eguchi, H. Dewar, S. Kohin, D.P. Costa, L.B. Crowder, R. L. Lewison, A dynamic ocean management tool to reduce bycatch and support sustainable fisheries, Sci. Adv. 4 (2018) 3001, https://doi.org/10.1126/sciadv. aar3001.

[99] N. Queiroz, N.E. Humphries, A. Couto, M. Vedor, I. da Costa, A.M.M. Sequeira, G. Mucientes, A.M. Santos, F.J. Abascal, D.L. Abercrombie, K. Abrantes, D. AcuñaMarrero, A.S. Afonso, P. Afonso, D. Anders, G. Araujo, R. Arauz, P. Bach, A. Barnett, D. Bernal, M.L. Berumen, S. Bessudo Lion, N. Bezerra, A.V. Blaison, B. A. Block, M.E. Bond, R. Bonfil, R.W. Bradford, C.D. Braun, E.J. Brooks, A. Brooks, J. Brown, B.D. Bruce, M.E. Byrne, S.E. Campana, A.B. Carlisle, D.D. Chapman, T. K. Chapple, J. Chisholm, C.R. Clarke, E.G. Clua, J. Cochran, E.C. Crochelet, L. Dagorn, R. Daly, D.D. Cortés, T.K. Doyle, M. Drew, C. Duffy, T. Erikson, E. Espinoza, L.C. Ferreira, F. Ferretti, J.D. Filmalter, G.C. Fischer, R. Fitzpatrick, J. Fontes, F. Forget, M. Fowler, M.P. Francis, A.J. Gallagher, E. Gennari, S. D. Goldsworthy, M.J. Gollock, J.R. Green, J.A. Gustafson, T.L. Guttridge, H. M. Guzman, N. Hammerschlag, L. Harman, F. Hazin, M. Heard, A.R. Hearn, J. C. Holdsworth, B.J. Holmes, L.A. Howey, M. Hoyos, R.E. Hueter, N.E. Hussey, C. Huveneers, D.T. Irion, D. Jacoby, O. Jewell, R. Johnson, L. Jordan, S. J. Jorgensen, W. Joyce, C.A. Keating Daly, J.T. Ketchum, A.P. Klimley, A.A. Kock, P. Koen, F. Ladino, F.O. Lana, J. Lea, F. Llewellyn, W.S. Lyon, A. MacDonnell, B. Macena, H. Marshall, J.D. McAllister, R. McAuley, M.A. Meÿer, J.J. Morris, E. R. Nelson, Y.P. Papastamatiou, T.A. Patterson, C. Peñaherrera-Palma, J. G. Pepperell, S.J. Pierce, F. Poisson, L.M. Quintero, A.J. Richardson, P.J. Rogers, C.A. Rohner, D. Rowat, M. Samoilys, J.M. Semmens, M. Sheaves, G. Shillinger,
M. Shivji, S. Singh, G.B. Skomal, M.J. Smale, L.B. Snyders, G. Soler, M. Soria, K. M. Stehfest, J.D. Stevens, S.R. Thorrold, M.T. Tolotti, A. Towner, P. Travassos, J. P. Tyminski, F. Vandeperre, J.J. Vaudo, Y.Y. Watanabe, S.B. Weber, B. M. Wetherbee, T.D. White, S. Williams, P.M. Zárate, R. Harcourt, G.C. Hays, M. G. Meekan, M. Thums, X. Irigoien, V.M. Eguiluz, C.M. Duarte, L.L. Sousa, Global spatial risk assessment of sharks under the footprint of fisheries, Nature 572 (2019) 461-466, https://doi.org/10.1038/s41586-019-1444-4.

[100] S. Brodie, M.G. Jacox, S.J. Bograd, H. Welch, H. Dewar, K.L. Scales, S.M. Maxwell, D.M. Briscoe, C.A. Edwards, L.B. Crowder, R.L. Lewison, E.L. Hazen, Integrating dynamic subsurface habitat metrics into species distribution models, Front. Mar. Sci. 5 (219) (2018), https://doi.org/10.3389/fmars.2018.00219.

[101] B.A. Muhling, R. Brill, J.T. Lamkin, M.A. Roffer, S. Lee, Y. Liu, F.E. Muller-Karger, Projections of future habitat use by atlantic bluefin tuna: mechanistic vs. correlative distribution models, ICES J. Mar. Sci. 74 (3) (2017) 698-716.

[102] T. Tanhua, S. Pouliquen, J. Hausman, K. O'Brien, P. Bricher, T. de Bruin, J. Buck, E.F. Burger, T. Carval, K.S. Casey, S. Diggs, A. Giorgetti, H. Glaves, V. Harscoat, D. Kinkade, J.H. Muelbert, A. Novellino, B. Pfeil, P.L. Pulsifer, A. Van de Putte, E. Robinson, D. Schaap, A. Smirnov, N. Smith, D. Snowden, T. Spears, S. Stall, M. Tacoma, P. Thijsse, S. Tronstad, T. Vandenberghe, M. Wengren, L. Wyborn, Z. Zhao, Ocean FAIR data services, Front. Mar. Sci. 6 (2019), https://doi.org/ 10.3389/fmars.2019.00440.

[103] D. De Pooter, W. Appeltans, N. Bailly, S. Bristol, K. Deneudt, M. Eliezer, E. Fujioka, A. Giorgetti, P. Goldstein, M. Lewis, M. Lipizer, K. Mackay, M. Marin, G. Moncoiffé, S. Nikolopoulou, P. Provoost, S. Rauch, A. Roubicek, C. Torres, A. van de Putte, L. Vandepitte, B. Vanhoorne, M. Vinci, N. Wambiji, D. Watts, E. Klein Salas, F. Hernandez, Toward a new data standard for combined marine biological and environmental datasets - expanding OBIS beyond species occurrences, Biodivers. data J. 5 (2017) 10989, https://doi.org/10.3897/BDJ.5. e10989.

[104] R.A. Simons, ERDDAP. 〈https://coastwatch.pfeg.noaa.gov/erddap $\rangle$. Monterey, CA: NOAA/NMFS/SWFSC/ERD (accessed January 2019).

[105] World Meteorological Organization (WMO), The Global Observing System for Climate: Implementation Needs (GCOS-200 (GOOS-214); p. 342). World Meteorological Organization, 2016. 〈https://library.wmo.int/opac/doc_num. php? explnum_id=3417 $\rangle$ (accessed September 2020).

[106] D. Vorisek, Y. Shu, Understanding the Cost of Achieving the Sustainable Development Goals. Policy Research Working Paper 9146. World Bank Group, 2020. 〈http://documents1.worldbank.org/curated/en/744701582827333101/ pdf/Understanding-the-Cost-of-Achieving-the-Sustainable-Development-Goals. pdf (accessed 27 September 2020).

[107] J.H. Muelbert, N.J. Nidzieko, A.T.R. Acosta, S.E. Beaulieu, A.F. Bernardino, E. Boikova, T.G. Bornman, B. Cataletto, K. Deneudt, E. Eliason, A. Kraberg, M. Nakaoka, A. Pugnetti, O. Ragueneau, M. Scharfe, T. Soltwedel, H.M. Sosik, A. Stanisci, K. Stefanova, P. Stéphan, A. Stier, J. Wikner, A. Zingone, ILTER. The international long-term ecological research network as a platform for global coastal and ocean observation, Front. Mar. Sci. 6 (527) (2019), https://doi.org/ 10.3389/fmars.2019.00527.

[108] N.J. Bax, W. Appeltans, R. Brainard, J.E. Duffy, P. Dunstan, Q. Hanich, H. Harden Davies, J. Hills, P. Miloslavich, F.E. Muller-Karger, S. Simmons, O. AburtoOropeza, S. Batten, L. Benedetti-Cecchi, D. Checkley, S. Chiba, A. Fischer, M. Andersen Garcia, J. Gunn, E. Klein, R.M. Kudela, F. Marsac, D. Obura, Y. J. Shin, B. Sloyan, T. Tanhua, J. Wilkin, Linking capacity development to GOOS monitoring networks to achieve sustained ocean observation, Front. Mar. Sci. 5 (2018), https://doi.org/10.3389/fmars.2018.00346.

[109] GOSR, Global Ocean Science Report: The Current Status of Ocean Science around the World, (IOC Policy Series 2017-1; IOC/POL/2017/1), 2017.

[110] GOSR, in: K. Isensee (Ed.), Global Ocean Science Report 2020-Charting Capacity for Ocean Sustainability, UNESCO Publishing, Paris, 2020.

[111] D. Lear, P. Herman, G. Van Hoey, L. Schepers, N. Tonne, M. Lipizer, et al., Supporting the essential - recommendations for the development of accessible and interoperable marine biological data products, Mar. Policy 117 (103958) (2020), https://doi.org/10.1016/j.marpol.2020.103958.

[112] K. Recinos, L. Blue, Improving capacity development for threatened maritime and marine cultural heritage through the evaluation of a parameter framework, J. Mari Arch. 14 (2019) 409-427, https://doi.org/10.1007/s11457-019-09246-9.

[113] S. Levitus, The UNESCO-IOC-IODE "Global Oceanographic Data Archeology and Rescue" (GODAR) Project and "World Ocean Database" Project, Data Sci. J. 11 (2012) 46-71, https://doi.org/10.2481/dsj.012-014.

[114] E.P. Fenichel, E.T. Addicott, K.M. Grimsrud, G. Lange, L. Porras, B. Milligan, Modifying national accounts for sustainable ocean development, Nat. Sustain 3 (2020) 889-895, https://doi.org/10.1038/s41893-020-0592-8.

[115] UN Convention on Biological Diversity, Proposed indicators and monitoring approach for the post-2020 global biodiversity framework, CBD/SBSTTA/24/3/ Add.1, 2020.

[116] N. Pacoureau, C.L. Rigby, P.M. Kyne, R.B. Sherley, H. Winker, J.K. Carlson, S. V. Fordham, R. Barreto, D. Fernando, M.P. Francis, R.W. Jabado, K.B. Herman, K. M. Liu, A.D. Marshall, R.A. Pollom, E.V. Romanov, C.A. Simpfendorfer, J.S. Yin, H.K. Kindsvater, N.K. Dulvy, Half a century of global decline in oceanic sharks and rays, Nature 589 (2021) 567-571.

[117] M. Bejder, D.W. Johnston, J. Smith, A. Friedlaender, L. Bejder, Embracing conservation success of recovering humpback whale populations: evaluating the case for downlisting their conservation status in Australia, Mar. Policy 66 (2016) 137-141. 
[118] M.I. Escobar-Pemberthy, Implementation of multilateral environmental agreements: rationale and design of the Environmental Conventions Index, Sustainability 12 (17) (2020) 7098, https://doi.org/10.3390/su12177098.

[119] A.D. Rogers, O. Aburto-Oropeza, et al., Critical Habitats and Biodiversity: Inventory, Thresholds and Governance, World Resources Institute, Washington,
DC, 2020 (Available online at), /www.oceanpanel.org/blue-papers/critical-habit ats-and-biodiversity-inventory-thresholds-and-governance〉.

[120] IOC, Revised draft implementation plan for the United Nations Decade of Ocean Science for Sustainable Development. IOC/EC-53/4.1.Doc (2), 2020. 